Supply chain collaboration and eco-innovations: An institutional perspective from China

Hofman, P.S., Blome, C., Schleper, M.C., Subramanian, N.

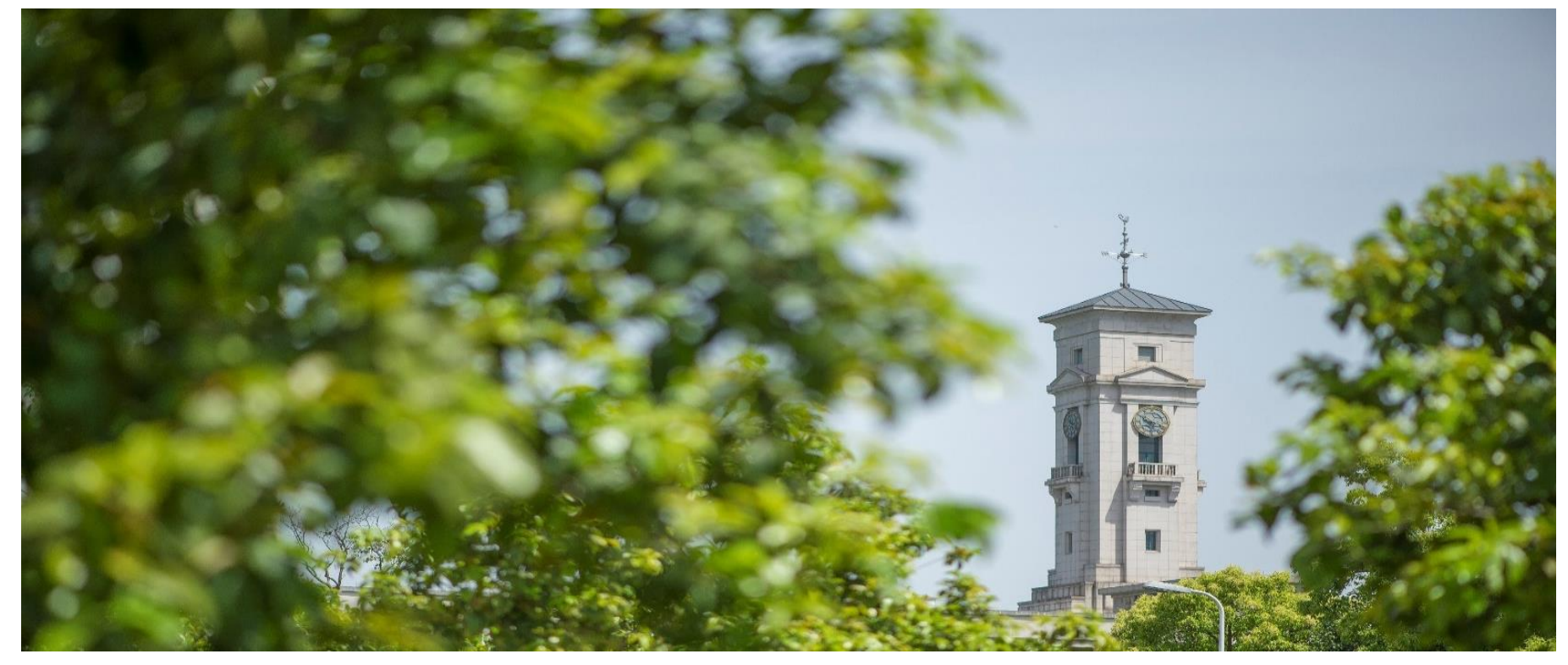


University of Nottingham Ningbo China, 199 Taikang East Road, Ningbo, 315100, China

First published 2020

This work is made available under the terms of the Creative Commons Attribution 4.0 International License:

http://creativecommons.org/licenses/by/4.0

The work is licenced to the University of Nottingham Ningbo China under the Global University Publication Licence:

https://www.nottingham.edu.cn/en/library/documents/researchsupport/global-university-publications-licence.pdf Nottingham 


\title{
SUPPLY CHAIN COLLABORATION AND ECO-INNOVATIONS: An Institutional Perspective from China
}

\author{
Peter S. Hofman \\ Nottingham University Business School China \\ Peter.Hofman@nottingham.edu.cn \\ Constantin Blome \\ University of Sussex Business School, UK \\ C.Blome@sussex.ac.uk \\ Martin C. Schleper \\ University of Sussex Business School, UK \\ M.C.Schleper@sussex.ac.uk \\ Nachiappan Subramanian \\ University of Sussex Business School, UK \\ N.Subramanian@sussex.ac.uk \\ Accepted for publication in \\ Business Strategy and the Environment \\ 12 May 2020
}

\begin{abstract}
This study explores the impact of supply chain collaboration on eco-innovations in the context of 220 Chinese manufacturing supplier firms involved in global supply chain networks. It investigates how supplier and customer collaborations help firms to enhance product eco-innovations, and/or process eco-innovations, and how the institutional context (i.e., regulatory, market, and community pressures) influences these relationships. The structural equation modeling approach is used to analyze the data captured from medium and large manufacturing enterprises in three major sectors: automotive; electronics; and textiles. The results show that community pressure has a positive effect on supplier collaboration, which further leads to enhanced process eco-innovation. On the other hand, the findings indicate that while market pressure enhances customer collaboration this does not reinforce product eco-innovation. Contrary to our expectation, regulatory pressures do not impact supplier or customer collaboration for innovation. Overall, different institutional factors indicate divergent effects on supply chain collaboration and product/process eco-innovation. The importance of normative pressures, such as those applied through the local community and interest groups, for eco-innovations in production processes is further discussed as a typical feature of the institutional environment of Chinese supplier firms.
\end{abstract}

Keywords: China; customer collaboration; eco-innovation; supplier collaboration; sustainable supply chain management; institutional theory 


\section{SUPPLY CHAIN COLLABORATION AND ECO-INNOVATIONS: An Institutional Perspective from China}

\section{INTRODUCTION}

The capability to innovate traditionally is considered a critical factor for the long-term success of firms (Lengnick-Hall, 1992). Over recent decades, this capability has gradually transcended the mere economic dimension and firms have increasingly become aware of ecological and social requirements (Amui, Jabbour, de Sousa Jabbour \& Kannan, 2018). Firms need to consider these requirements in the development of new products, processes, and services (Hart \& Dowell, 2011; Gao, Xu, Ruan, \& Lu, 2017; Mülling Neutzling, Land, Seuring \& do Nascimento, 2018). By definition, eco-innovations, as the ecological (green) subset of sustainable innovations, comprise "the process of developing new products, processes or services which provide customer and business value but significantly decrease environmental impact" (Fussler \& James, 1996, p. 303). Thus, eco-innovations display a lower environmental footprint than predecessors; either in terms of the environmental impact caused during the manufacturing stage (i.e., process eco-innovations), or in terms of the environmental impact of the product as it is being used over its life-cycle (i.e., product eco-innovations) (Rennings, 2000; OECD, 2009; Costantini, Crespi, Marin, \& Paglialunga 2017).

Due to changes in the regulatory environment, market pressure, and shifts in stakeholders' expectations - including consumers, buying firms, NGOs, local communities, and the broader society - firms are under increasing scrutiny to improve their sustainability performance and to yield eco-innovations (Horbach, 2008; Zhu, Cordeiro, \& Sarkis, 2012a; Ociepa-Kubicka \& Pachura, 2017). This is also increasingly the case in China as the world's second largest economy where the environmental degradation associated with rapid economic growth in the past decade has led to increasing pressure from civil society and central government to enhance the environmental performance of firms (Marquis, Zhang \& Zhou, 2011; Van Rooij, Stern \& Fürst, 2016).

Supply chain collaboration is an important factor in successfully developing innovations and eco-innovations as strategically working together with suppliers and/or customers can help to develop solutions for environmental and social problems (Nieto \& Santamaria, 2007; Dangelico, Pontrandolfo, \& Pujari, 2013; Roscoe, Cousins, \& Lamming, 2016; Melander, 2018; Mülling Neutzling et al., 2018; for a detailed overview see Adams, 
Jeanrenaud, Bessant, Denyer, \& Overy, (2016) and Melander (2017)). Although some studies have addressed the drivers for product and process eco-innovations (e.g., Lee \& Kim, 2011; Doran \& Ryan, 2016; Garrone, Grilli, \& Mrkajic, 2018; Zhang \& Zhu, 2019), the influence of different collaboration forms on process, as well as product eco-innovations and their underlying institutional pressures, remains opaque.

Consequently, this study's objectives are to investigate: a) the impact of institutional pressures towards eco-innovations on two different types of supply chain collaboration (i.e., supplier and customer collaboration); and, b) whether these collaboration types influence the development of process and product eco-innovations. A focus on the context of Chinese manufacturing suppliers active in global supply chains in automotive, electronics, and textile industries allows this study to capture the dynamics of collaboration and the development of eco-innovations in critical production locations (Zhu et al., 2012a; Chen, Cheng, \& Dai, 2017a). It is expected that these supplier firms adopt environment-friendly processes and products as a way to achieve and maintain higher degrees of legitimacy in response to regulatory, normative, and market pressures. In addition, they aim to maintain and enhance their relationships with buying firms (Dyer \& Singh, 1998; Scott, 2001; Campbell, 2007; Zeng, Chen, Xiao, \& Zhou, 2017; Zhu, Qu, Geng, \& Fujita, 2017). Moreover, it is timely to investigate this in the context of China given its critical role as the world's leading manufacturing base in supply chains, and also the increasing attention to environmental and social aspects of Chinese firms, both domestically and along their supply chains. There have been increasing calls for more responsible social and environmental business practices by societal actors and government in China. This is illustrated by Xi Jinping's address to the National Congress in 2017 where he called for an accelerated building of ecological civilization and announced that "we will take tough steps to stop and punish all activities that damage the environment" (Xi Jinping, 2017).

By integrating an institutional theory perspective (Scott, 1994; Scott, 2001) with a relational perspective (Dyer \& Singh, 1998) to investigate product and process eco-innovations in Chinese supplier firms, this study contributes to the understanding of supply chain collaboration and eco-innovation in two ways. First, it brings an institutional perspective to explain the nature of supply chain collaboration within Chinese supplier firms, arguing that the nature of perceived institutional pressures shapes the type of collaboration with either suppliers or buyers/customers. Second, it investigates how institutional pressures impact supply chain collaboration and how this in turn might affect a firm's inclination towards process and/or product eco-innovations. So far, only a few studies have been conducted which differentiate 
the type of eco-innovation with regard to their drivers (exceptions include e.g., Wagner, 2007; Del Río, Carrillo-Hermosilla, \& Könnölä, 2010; Zubeltzu-Jaka, Erauskin-Tolosa, \& HerasSaizarbitoria, 2018; Zhang \& Zhu, 2019).

The results show that regulatory pressure does not trigger collaboration for the development of eco-innovations, whereas community pressure does have a significant impact on supplier collaboration, which consequently enhances process eco-innovations. Community pressure is not found to impact customer collaboration. Market pressure is positively correlated with customer collaboration and negatively with supplier collaboration, but this has no further consequences in terms of enhancing eco-innovations.

The remainder of the paper is structured as follows: the next section presents an indepth review of the literature based on which ten hypotheses are developed with regard to the relationships between institutional pressures, supply chain collaboration, and product and process eco-innovation. Thereafter, the methodology is introduced, including the summary of the main variables, the sampling approach, the data collection and its analysis. The sections that follow outline the findings. The discussion and concluding sections discuss theoretical and practical implications, highlight the study's limitations, and suggest potential research avenues.

\section{LITERATURE REVIEW}

\subsection{Eco-innovations}

Although the literature suggests that finding a definition for "eco-innovation" can prove difficult due to a plethora of similar terms, such a "green innovation", "sustainable innovation", "eco-innovation", or "environmental innovation" (Dias Angelo, Jabbour, \& Vasconcellos Galina, 2012), this study uses “eco-innovation” as its main concept and does so interchangeably with these adjacent terms.

Eco-innovation can be defined as "the implementation of new, or significantly improved, products (goods or services), processes, marketing methods, organizational structures and institutional arrangements which, with or without intent, lead to environmental improvements compared to relevant alternatives" (OECD, 2009). Similarly, Costantini et al. (2017) describe eco-innovations as: the production, assimilation, or exploitation of product or production processes; and, the service, management, or business methods novel to the organization. Each cover the product life cycle, with the end effect of reducing environmental risk, pollution, and other negative impacts of resource use compared to alternatives. Despite 
these general definitions, previous studies also suggest differentiation between incremental and radical eco-innovations (Klewitz \& Hansen, 2014; Roscoe et al., 2016).

Over the past decade, many studies have contributed to the analysis of antecedents of eco-innovation as well as the link between eco-innovations and firm performance. A variety of external and internal factors, such as: service capability (Fernando, Jabbour and Wah, 2019); dynamic capabilities (Wu, Liao, Chen, Lin, \& Tsai, 2016); human resource factors (Jabbour, Neto, Gobbo Jr., de Souza Ribeiro, \& de Sousa Jabbour, 2015) and training (Neto, Jabbour, \& de Sousa Jabbour, 2014); as well as absorptive capacity (Zhang, Liang, Feng, Yuan, \& Jiang, 2020), have been investigated, with different impacts on the development of eco-innovations.

In their meta-analysis of these topics, Zubeltzu-Jaka et al. (2018) identify four categories of drivers which have been regularly found in prior studies: technology push; market pull; regulatory push-pull; and, firm specific factors. However, in their own analysis, they find that "firms with collaborative networks and/or more environmental concerns are more prone to eco-innovate, emphasizing the role of "technology push" as the main cluster of determinants, regardless of whether a typology of eco-innovation is included as a moderator in the metaanalysis" (Zubeltzu-Jaka et al., 2018, p.1).

With regard to performance implications, the literature provides a rather mixed, opaque, and inconclusive picture of the relationship between concepts (Doran and Ryan, 2016; Tang, Walsh, Lerner, Fitza, \& Li, 2018). Whereas some studies find a negative relationship between eco-innovations and firm performance (e.g., Liu et al., 2011; Driessen, Hillebrand, Kok, \& Verhallen, 2013), others indicate a positive relationship (Dangelico, 2016). These mixed findings induced Tang et al.'s (2018) study that, in the context of China, finds that managerial concern for environmental issues is an important moderator in this relationship.

In their systematic literature review, Pacheco, ten Caten, Jung, Ribeiro, Navas, and Cruz-Machado (2017) investigate eco-innovation determinants in the context of manufacturing SMEs, a subset of firms for which they find adequate research is underdeveloped. Critical determinants identified by them include: governmental policies which support the development and implementation of eco-innovations; the availability of resources (i.e., people, technology, knowledge); the perception of the strategic relevance of eco-innovations; technological advisory oriented to the environment; product and process eco-innovation-oriented methods; cooperation and partnership within supply networks (Pacheco et al., 2017).

Tang et al. (2018) point out that very few studies related to eco-innovations have focused on China in the past despite its importance as one of the largest economies in the world with a vast manufacturing sector, and thus representing one of the biggest environmental 
footprints. Exceptions include the work of Guoyou, Saixing, Chiming, Haitao, and Hailiang (2013) who study the impact of stakeholders on eco-innovations in Chinese manufacturing firms. They find that while foreign customers are crucial in influencing firms' eco-innovation strategies, community and regulatory stakeholders have no significant impact in this regard (Guoyou et al., 2013). Cai and Zhou (2014) explore potential internal and external drivers of eco-innovations in China in different industries. Their results confirm the important role of the demand side for environmental eco-innovations as well as environmental regulations, but at the same time they emphasize the role of internal drivers as a bridge function in these links (Kesidou \& Demirel, 2012; Cai \& Zhou, 2014).

Peng and Liu (2016) study the impact of managerial perceptions (i.e., managerial environmental risk awareness and managerial cost-benefit awareness) and resource acquisition (i.e., from business and political networks) on eco-management, eco-process, and eco-product innovation activities. Their main contribution lies within the suggestion that it is not the external environment per se that influences eco-innovation, but the managerial perception and interpretation of these environments (Peng \& Liu, 2016).

Chen et al. (2017a) developed a measurement index system to measure the regional eco-innovation development in 30 Chinese provinces during the period of 2000 to 2014 . They find that eco-innovation in China is increasing, while the intensity of eco-innovation is higher in the more developed East compared to the less developed West. Furthermore, their study finds that technology push, market pull, and environmental regulation pull have a positive, but differentiated, influence on eco-innovation throughout China (Chen et al., 2017a).

\subsection{Institutional Theory}

According to institutional theory, organizations exist in specific implicit and explicit contexts (i.e., institutional environments) which consist of "symbolic and behavioral systems containing representational, constitutive, and normative rules together with regulatory mechanisms that define a common meaning system and give rise to distinctive actors and action routines" (Scott, 1994, p. 86). These institutional environments - represented by governing bodies, the wider public and/or local communities, the media and industry associations provide guidelines, rules, cultural settings and routines to which these organizations tend to adhere in order to gain legitimacy as a prerequisite to access to resources for their survival and to uphold their social status (Meyer \& Rowan, 1977; Bansal, 2005; Campbell, 2007).

Although institutional theory states that organizations are subject to both pressures from technical aspects and at the institutional level, the main tenet of institutional theory is that 
organizations tend to become isomorphic over time as a result of institutional pressures comprising of coercive, normative, and mimetic pressure (Colwell \& Joshi, 2013). Whereas coercive pressure evolves from institutions in a firm's environment which formulate the rules and guidelines with which a firm needs to comply, mimetic pressure stems from voluntary actions through imitation of legitimate and successful peers in an organization's institutional environment (DiMaggio \& Powell, 1983). Thus, mimetic pressure evolves from behavioral uncertainty on how to solve a specific problem, perform a specific activity or reach a specific goal (DiMaggio \& Powell, 1983). Finally, normative pressure results from norms specified by institutions, such as professional or industry associations, and thereby presents a "socialization of an organization within its institutional environment" to ascertain conformity with institutional demands (DiMaggio \& Powell, 1983; Oliver, 1991; Colwell \& Joshi, 2013, p. 75).

The institutional environment in which Chinese supplier firms operate exerts significant pressures on these firms to conform to what constitutes appropriate and legitimate behavior (Zeng et al., 2017). Prominent barriers with respect to the least eco-innovative countries are: uncertain demand from the market; uncertain return on investment or a payback period too lengthy for eco-innovations; lack of funds within the enterprise; and insufficient access to existing subsidies and fiscal incentives (Ociepa-Kubicka \& Pachura, 2017). In particular, companies in emerging economies are afraid of financial risks which raise uncertainty and this leads them to refrain from the incorporation of innovative initiatives (Ociepa-Kubicka \& Pachura, 2017).

\subsection{Linking institutional theory and supply chain collaboration outcomes}

So far, a wide range of studies has focused on the direct effects of institutional pressures on eco-innovations. Whereas vast confirmation of the impact of regulatory effects on ecoinnovations has been found (Zhang et al., 2020), results regarding the link between normative and mimetic pressures and eco-innovations are more mixed (Rennings, 2000; Horbach, 2008; Frondel, Horbach, \& Rennings, 2008; Horbach, Rammer, \& Rennings, 2012; Triguero, Moreno-Mondéjar, \& Davia, 2013). However, in this section, it is argued that effects between institutional pressures and eco-innovations are mediated through supplier and/or customer collaboration (Sharfman, Gray, \& Yan, 1991).

Previous research has commonly categorized supply chain sustainability practices into two categories: collaboration and monitoring (Vachon \& Klassen, 2006; Parmigiani, Klassen, \& Russo, 2011; Gimenez \& Tachizawa, 2012; Danese, Lion, \& Vinelli, 2019). Whilst monitoring focuses on evaluation and control rather than on supply (i.e., the upstream side), 
collaboration activities can entail different external stakeholders, such as customers, suppliers, NGOs, universities and research institutes, competitors, etc., with the overall aim to improve the environmental performance of products and processes (Danese et al., 2019).

Our main hypotheses revolve around the assumption that the different institutional pressures (i.e., regulatory, market, and community) motivate firms towards a higher engagement in supply chain collaboration (i.e., supplier and customer collaboration) with the ultimate goal of increased eco-innovation development/implementation behavior.

This correlation is posited because Western buying firms, governments, NGOs, international organizations, media, and other stakeholders, increasingly expect firms to improve their sustainability performance. However, Chinese supplier firms may need to enhance their capacity and capabilities for eco-innovations, for example through collaboration, as environmental issues are not among the core competencies of these firms and the return of investment of eco-innovations are usually more uncertain (De Marchi, 2012; Ardito, Petruzzelli, Pascucci, \& Peruffo, 2019).

Consequently, engaging in such forms of collaboration towards eco-innovations provides a way to hedge against lost investments (Cainelli, De Marchi, \& Grandinetti, 2015) and to maintain and enhance legitimacy. Cooperation and collaboration are important drivers for effective eco-innovation engagement and development (e.g., Foray \& Grübler, 1996; Lee \& Kim, 2011; Wagner \& Llerena, 2011; Melander, 2018).

As prior studies indicate that different outcomes depend on the type of supply chain collaboration, we distinguish between supplier collaboration and customer collaboration as its two main forms. These extant studies suggest that institutional pressure for collaboration varies among upstream and downstream supply chains. Upstream supply chains will follow cooperative approaches to train and help suppliers, while downstream supply chains will adopt coercive approaches, such as command and control, based on customers' requests (Hoejmose et al., 2014). A review on collaboration and sustainability by Chen et al. (2017) acknowledges the difficulty in comparing the impact of collaboration with suppliers and customers and suggests that future research should analyze whether differences in upstream collaboration and downstream collaboration could create different sustainable outcomes. Hence, this study aims to understand the impact of institutional pressures on upstream and downstream collaboration and sustainable outcomes.

\subsubsection{Effect of regulatory pressure on collaboration}


Previous studies show that coercive (i.e., regulatory) pressure is a crucial factor for the development and implementation of eco-innovations (Horbach et al., 2012; Del Río, Peñasco, \& Romero-Jordán, 2015; Bossle, de Barcellos, Vieira, \& Sauvée, 2016; Liao, 2018a).

Although previous studies find the strictness and influence of these regulatory pressures to vary between countries (Zhu et al., 2017), governments and regulatory bodies constitute crucial factors when it comes to firms' environmental performance (Darnall, Potoski, \& Prakash, 2010; Zhu et al., 2017). Thus, we postulate that regulatory pressure fosters firms' responses to engage in supply chain collaboration to enhance the development and implementation of product and process eco-innovations.

In the context of 188 Chinese firms, Wang, Li, and Zhao (2017) find that regulatory pressure is related to a firm's implementation of environmental management practices, such as the development of eco-innovations. However, they also claim that this correlation is dependent on the firm's environmental commitment and resources (Wang et al., 2017).

Tsai and Liao (2017) partially support these findings when they indicate that innovation capacity has different effects on eco-innovations. Yet, by differentiating between current and anticipated regulatory pressure, their findings show that current regulations have a negative correlation with the development and implementation of eco-innovations, whereas anticipated regulations have a positive impact (Tsai \& Liao, 2017).

Together with national regulations, international environmental product and process standards, such as ISO14001, the European directives REACH (Registration, Evaluation and Authorization of Chemicals), WEEE (Waste Electrical and Electronic Equipment), or the EUand the China-RoHS (Restriction of Hazardous Substances) provide strong requirements to which many industries and manufacturers must adhere. Moreover, as mentioned in the introduction, the Chinese government and communist party have, in recent years, placed more emphasis on the reduction of environmental impacts of companies which can be expected to intensify the implementation and enforcement of environmental regulations (Marquis et al., 2011; Xi Jinping, 2017).

As a result of these regulatory pressures, some firms build on supply chain collaborations as they realize they are not capable of achieving ambitious environmental goals on their own (Vachon \& Klassen, 2006; 2008; Ramanathan, Bentley, \& Pang, 2014). Customers depend on suppliers to achieve their environmental targets, as prominent examples of joint efforts over the supply chain to reduce emissions in logistics and operations illustrate (Oglethorpe, 2010). Thus, we propose: 
Hypothesis 1a: Regulatory pressure is positively associated with customer collaboration towards eco-innovation.

Hypothesis 1 b: $\quad$ Regulatory pressure is positively associated with supplier collaboration towards eco-innovation.

\subsubsection{Effect of market pressure on collaboration}

Similar to the arguments mentioned above, we postulate that market pressure triggers firms' responses to engage in supply chain collaboration to enhance the development and implementation of product and process eco-innovations. A range of studies has confirmed that market demand, customer requirements, and the performance of competitors have a significant effect on eco-innovations (Horbach et al., 2012; Kesidou \& Demirel, 2012; Triguero et al., 2013; Guoyou et al., 2013; Wu, 2015).

Previous research illustrates that manufacturing firms feel pressured to improve environmental performance based on guidelines developed by their customers (Bansal \& Roth, 2000; Zhu et al., 2012a, Busse, Schleper, Niu, \& Wagner, 2016) as environmentally certified processes, management systems, such as ISO14001, and products are necessary to allow entry to many Western and global markets (Christmann, 2004; Guoyou et al., 2013). Hall (2000, p. 456) even suggests that many of these innovations "were initiated by customer firms in response to market pressures, often with resistance from supplier firms who were not directly exposed to these market pressures".

Reflecting on these customer demands from the suppliers' perspective, the latter might seek competitive advantage over their competitors through the proactive development of ecoinnovations and overall sustainability performance. For instance, Loureiro and Lotade (2005) find, in a B2B context, that consumers are willing to pay more for environmentally labelling programs with respect to coffee; and Doran and Ryan (2012) emphasize the customer perception as a driver of a firm's decision to engage in eco-innovation. Kammerer (2009) depicts a more nuanced picture by highlighting the crucial role of customer benefits for ecoinnovations. More recently, Goebel, Reuter, Pibernik, Sichtmann, and Bals (2018) find a purchasing managers' willingness to pay for sustainable products in B2B contexts can lead to higher profits on the supplier's side.

Besides customer demands, several studies acknowledge the importance of competitors' behaviors and activities towards environmental performance (e.g. Lewis and Harvey, 2001; Dai, Cantor, \& Montabon, 2015). Cai and Li (2018) find the competitive 
environment of a firm as the primary driver towards eco-innovation, even before regulatory pressure. Furthermore, previous research finds that examples of green innovations adopted and/or developed by competitors can also trigger imitative behavior in firms (Yalabik \& Fairchild, 2011; Dai et al., 2015).

Against this background, studies highlight the positive effects of integrating external stakeholders towards eco-innovation and sustainable new product development, often with a focus on close supply chain partners, such as suppliers (e.g., Tan \& Tracey, 2007; De Marchi, 2012; Gmelin \& Seuring, 2014). As it is virtually impossible to have all skills and knowledge in-house for firms to successfully engage in eco-innovations, customers and suppliers present a valuable source for collaboration (Goodman, Korsunova, \& Halme, 2017; Melander, 2018). While suppliers might contribute mainly on the material and technology side, customers can provide crucial information and knowledge about products, services, and markets (Geffe and Rothenberg, 2000; Dai et al., 2015; Melander, 2018). Consequently, Lee and Kim (2011, p. 528) advocate to "integrate strategic inputs from suppliers (...) and inputs from a variety of managerial and technological functional areas of suppliers" as these could "prove beneficial to management, particularly [in] green product innovation". This is in line with Geffen and Rothenberg (2000) who find strong partnerships with suppliers to be one of the key drivers in the development of innovative environmental technologies due to the specific expertise of suppliers.

Consistent with these arguments, Yen (2018) and others (e.g., Lee, 2008; Liu, Yang, Wang, Shishime, \& Bao, 2012) find a significant impact of customer demands on buyersupplier collaboration in the green practices of Chinese firms. Furthermore, the study shows an indirect effect of competitor pressure (through customer pressure) on environmental buyersupplier collaboration; which means that "once customers have detected competing suppliers with superior green practices, they force their current suppliers to keep pace with or even outperform the competitive suppliers" (Yen, 2018, p. 8).

Lastly, Glover, Champion, Daniels and Dainty (2014) argue that investments in environmental technologies are usually linked to high costs and uncertainty, and thus they justify higher levels of supply chain collaboration to better serve the market and society.

Based on the line of argument outlined above, we posit that customer demands and competitive behavior (i.e., market pressure) have an impact on a firm's collaboration efforts as it seeks ways to improve environmental processes and greener products, and to keep abreast of competitors: 
Hypothesis 2a: $\quad$ Market pressure is positively associated with customer collaboration towards eco-innovation.

Hypothesis 2b: $\quad$ Market pressure is positively associated with supplier collaboration towards eco-innovation.

\subsubsection{Effect of community pressure on collaboration}

Local communities, defined as "those who are not necessarily involved in the business partnership directly but have knowledge of local companies" (Liu et al., 2012, p. 4), can involve members of trade associations, NGOs, and the media, but also the local society. Local communities can exert a strong normative stakeholder pressure in terms of environmental and social aspects (Sharma \& Henriques, 2005) as they provide a potential source for supply chain sustainability risks (Hofmann, Busse, Bode, \& Henke, 2014; Busse, Schleper, Weilenmann, \& Wagner, 2017). These stakeholders often attribute negative sustainability incidents in supply chains not only to local firms if these take place at their own sites, but also at their upstream suppliers, thus creating a "chain liability" effect and serious sustainable supply chain risks (Hartmann \& Moeller, 2014; Hofmann et al., 2014). To deal with these stakeholder-induced sustainability risks, and to hedge against them, collaboration-based risk mitigation is proposed as one potential approach (Foerstl, Reuter, Hartmann, \& Blome, 2010; Hajmohammad \& Vachon, 2016). Managers need to better manage and understand the normative demands of stakeholder groups and "should work to ensure sustainable behavior throughout the supply chain, to protect themselves from chain liability" (Hartmann \& Moeller, 2014, p. 291). Thus, it is vital for firms to "develop more profound capabilities for supplier development, collaboration, and innovation" (Hartmann \& Moeller, 2014, p. 291). Following this rationale, firms might engage even more in supply chain collaboration if local communities assess their legitimacy as being mainly part of an overall interlinked industry, rather than individual entities (Sharfman et al., 1991).

Previous studies show that firms which fail to respond to these normative stakeholder demands are prone to severe direct and indirect reactions from local communities (Pavlovich \& Akoorie, 2010), such as public boycotts, protests, or even sabotage (Hofmann et al., 2014; Busse et al., 2017) and that accommodating community stakeholders' expectations has the potential to improve the relationship with local stakeholders (Delmas \& Toffel, 2004; Zhang, Bi, Yuan, Ge, Liu, \& Bu, 2008). Moreover, in the last decade or so, civil society groups, such as communities and environmental NGOs, have become more prominent in China in voicing 
their concern, especially since Hu Jintao's administration when the concepts of harmonious society and ecological civilization were advanced (Marquis et al., 2011; Li, He, Shao, \& Cao, 2017).

Wang et al. (2017) find a positive significant link between normative pressure and the implementation of environmental practices contingent on commitment and resource availability. Thus, when it comes to demands to protect the environment and to improve environmental performance from local communities and other stakeholders, the development and implementation of eco-innovations provide a fruitful means for firms to fulfill these expectations (Qi, Shen, Zeng, \& Jorge, 2010; Berrone, Fosfuri, Gelabert, \& Gomez-Mejia, 2013). Consequently, Chinese manufacturing firms increasingly respond to these normative community pressures through the development and implementation of eco-innovations (Guoyou et al., 2013; Peng \& Liu, 2016).

This is in line with Tachizawa, Gimenez, and Sierra (2015) who disaggregate different drivers for collaboration into coercive and normative drivers in their study on green supply chain management approaches. In addition to their findings of a positive direct effect of collaboration activities on environmental performance, they also find a positive correlation between normative pressures and collaborative activities, but they do not find a significant effect of coercive pressures (Tachizawa et al., 2015).

On these grounds, we expect community pressure (i.e., normative pressure) to trigger firms' responses to engage in upstream and downstream supply chain collaboration to enhance the development and implementation of product and process eco-innovations and propose:

Hypothesis 3a: Community pressure is positively associated with customer collaboration towards eco-innovation.

Hypothesis 3 : $\quad$ Community pressure is positively associated with supplier collaboration towards eco-innovation.

\subsection{Environmental supply chain collaboration}

Environmental supply chain collaboration refers to "the planning and development of environmental activities and projects that require direct involvement of an organization whether with its suppliers or with its customers to jointly develop environmental solutions" (Vachon, 2007, p. 4359). In response to increased sustainability scrutiny by stakeholders, horizontal and vertical collaboration with other actors in and adjacent to their supply chains 
has become a strategic issue in order to deal with environmental and social aspects for many firms (Chen, Zhao, Tang, Price, Zhang, \& Zhu, 2017b).

Environmental supply chain collaboration has mainly been researched in prior studies with regard to its impact on environmental (e.g., Vachon \& Klassen 2006; 2008; Hollos, Blome, \& Foerstl, 2012) and economic performance (e.g., Large \& Giménez Thomsen, 2011), as well as potential drivers for environmental supply chain collaboration (e.g., Zhu \& Sarkis 2004; Vachon \& Klassen, 2006; Giménez Thomsen \& Tachizawa, 2012; Paulraj, Jayaraman, \& Blome, 2014).

Although environmental supply chain collaboration potentially includes a plethora of different environmentally focused practices and processes (e.g., reduction of emissions, waste and resource consumption through reverse logistics, remanufacturing, or recycling) (Zhu \& Sarkis, 2004), this study focuses mainly on collaboration for innovation. In a comprehensive systematic literature review, Gao et al. (2017) analyze previous literature to understand the links between sustainability, innovation, and supply chain management, and call for more research on the link between collaboration and sustainable innovations (Gao et al., 2017). Collaboration is a particularly important aspect for the achievement of sustainable innovations as cost pressures, shortened project cycles, and fierce competition are high barriers to such achievement individually (Silvestre, 2014). Through open communication, information, and cost sharing, a collaborative approach allows supply chain partners to share the burdens (e.g., risks, resources) and benefits of the innovation development and implementation process and to create complementary effects in innovation (Blome, Schoenherr, \& Kaesser, 2013). Ultimately, these effects carry the potential to foster the overall innovation and sustainability performance of actors (Silvestre, 2014; Gao et al., 2017).

\subsection{Linking environmental supply chain collaboration and eco-innovation outcomes}

The role of collaboration in the process of innovation has gained a central position in innovation research (Melander, 2017; Melander \& Pazirandeh, 2019). The development and implementation of eco-innovations is a complex endeavor which almost always requires external resource acquisition (Dangelico, Pujari, \& Pontrandolfo, 2017), e.g., external knowledge and information about environmental impacts external to an individual firm, thus external collaborations (De Marchi, 2012, Bossle et al., 2016; Peng \& Liu, 2016). Network partners help firms to identify and value relevant information and knowledge, such as specific knowledge about potential ways to reduce environmental impacts (Sharma \& Vredenburg, 1998). Collaborators in the supply chain can play an important role in the identification of 
specific environmental problems and the development of viable solutions that can be brought to the market (Dai et al., 2015); while collaboration with research institutes and universities allows firms to gain insight into fundamental approaches that can lead to more significant reductions in environmental impact (De Marchi \& Grandinetti, 2013). Triguero et al. (2013) find that collaboration has a significant positive effect on eco-innovation across SMEs in a range of European countries.

A number of studies have investigated the influence of collaboration on environmental practices and innovation in Chinese firms. In a study on technology-based SMEs, Malik and Wei (2011) find that partnerships play an increasingly important role for these firms to acquire and utilize external knowledge that can foster innovation. Zhu et al. (2012a) show that partnering with foreign firms positively affects the adoption of environmental practices, such as total quality environmental management and ISO14001 in Chinese firms. This indicates that collaborations with external partners, such as buyers, suppliers, and research institutes, help companies strengthen their environmental orientation and capacity to innovate. Cheung, Welford and Hills (2009), Hansen and Klewitz (2013) and Lewis, Cassells and Roxas (2015) demonstrate the importance of collaborative approaches in order to overcome SME's specific resource constraints towards higher levels of environmental responsibility and performance. Moreover, various studies find that internationalization and export orientation of Chinese firms is positively associated with innovative capabilities as it fosters closer relations with partners along the supply chains, such as customers who transfer relevant knowledge and information to supplier firms and promote a stronger innovative orientation of these firms (Salomon \& Shaver, 2005; Li, Chen, \& Shapiro, 2010). Overall, this leads to the postulation of the four following hypotheses (i.e., 4a-b and 5a-b) on the influence of customer and supplier collaboration on product and process eco-innovations.

\subsubsection{The effect of customer collaboration on eco-innovation}

Collaboration with customers/buyers is expected to forge a firm's orientation towards product and process eco-innovations as buyers/customers possess important information and knowledge on how to address environmental aspects from a marketing and downstream perspective. More specifically, we claim that firms collaborating with customers will lead to increased information sharing and knowledge exchange, resulting in improved product and process eco-innovations.

Hall (2000) points out that customer collaboration may result in increased capabilities, leading to both technical and organizational innovations. In the same line of argument, 
Dangelico et al. (2017) emphasize the importance of integrating customer demands about products' ecological performance as well as the integration of information on ecological impacts of products during customers' use in eco-innovation development.

Dai et al. (2015) investigate the role of green supply chain integration (i.e., internal, supplier, and customer) activities on radical and incremental environmental innovation. They find that while green supply chain integration has an overall positive impact on incremental environmental innovations, customer integration is the only factor that corresponds with radical ones (Dai et al., 2015). Knowing the environmental preferences of customers helps firms to find viable solutions for environmental aspects and to target markets in a more efficient way (Laroche, Bergeron, \& Barbaro-Forleo, 2001; Dai et al., 2015).

When investigating collaboration impacts on process innovations, Un and Asakawa (2015, p. 145) emphasize the importance of customer collaboration for product rather than process innovations. As customers focus on the output side, rather than the input side, “customers' input may help product innovation more than process innovation".

Still, we suppose that customers who are expected to continuously improve the environmental impact of their product lifecycles are, to a large extent, likely to pass these requirements on to their suppliers. Furthermore, we assume that customer collaboration will enhance the development and implementation of process eco-innovations as customers may share their experiences in ways which have the potential to reduce environmental impacts of the production process. Thus, we postulate:

Hypothesis 4a: Customer collaboration is positively associated with product ecoinnovation.

Hypothesis 4b: Customer collaboration is positively associated with process ecoinnovation.

\subsubsection{The effect of supplier collaboration on eco-innovation}

In the context of supplier collaboration towards process innovation, Un \& Asakawa (2015) do find a link between R\&D collaborations with suppliers and research institutes, although - as mentioned briefly above - this does not hold true for collaboration with customers or competitors. Similarly, De Marchi (2012) finds that collaboration is more important for the development and introduction of eco-innovations relative to regular innovation, with suppliers and research institutes as main partners that positively affect eco-innovation in firms. Whilst not differentiating between product/process, but between incremental/radical eco-innovations, 
Roscoe et al. (2016) also emphasize the importance of supplier collaboration for ecoinnovations. More specifically, they report that firms with strong ties with strategic suppliers will benefit from incremental eco-innovations, and that firms with weak ties with a multiple of their suppliers, as well as with suppliers bridging structural holes, will benefit from radical ecoinnovations (Roscoe et al., 2016).

Drawing on arguments from the extended resource based view, it can be argued that firms who collaborate with their suppliers have better access to strategic resources, knowledge and technologies, and capabilities which are imperative for the development and implementation of eco-innovations (Lewis, Brandon-Jones, Slack, \& Howard, 2010; Roscoe et al., 2016). Thus, we suggest that supplier collaboration can help to find ways to reduce environmental impacts along the lifecycle of products and to realize process eco-innovations that lead to reduced environmental impacts in production processes and postulate:

Hypothesis 5a: Supplier collaboration is positively associated with product ecoinnovation.

Hypothesis 5b: $\quad$ Supplier collaboration is positively associated with process ecoinnovation.

Figure 1 illustrates the conceptual model and hypotheses of our study.

*** Please insert Figure 1 approximately here ***

\section{METHODOLOGY}

Our intention in this study is to gain insight in the underlying supply chain collaboration that helps firms in global supply chains to develop new process and product eco-innovations and the way this is influenced by regulatory, market, and community pressures. To test the supply chain collaborative effect on eco-innovation we used a large-scale empirical survey within the specific country and industry context. We developed a survey instrument mostly based on standard measurement scales and, to some extent, adapted these scales to the environment to suit the requirements. Specific items for the variables are provided in the appendix. Sources of scales for different constructs in the model are as follows. The instrument was pre-tested with several companies before running the full survey. 


\subsection{Variables}

Institutional pressures as independent variables. We used items to measure regulatory pressure, market pressure, and community pressure on the sample firms, respectively. Sources for these independent variables are drawn from the community innovation survey (CIS, 2012), and items used for community pressure are utilized from Miller (1998) and Hsu (2008). The items used for market pressure are: current and future market demand from customers of lower environmental impact products; and, the influence of other firms that have gained substantial benefits through reduced environmental impact of their products and processes. The items used for community pressure are: neighborhoods' residents; environmental groups; and societal expectations for sustainable development and a harmonious society. Items used for regulatory pressure are existing and future environmental regulations. It should be emphasized that the regulatory construct can be conceptualized to represent a concrete and singular object where there is no need to have multiple items, this means the predictive validity will be the same when we measure the construct with single or multiple items (Bergkvist and Rossiter, 2007).

Product and process eco-innovation variables. The scales for the two dependent variables, product and process eco-innovations, were based upon earlier work from Arundel and Kemp (2000), Rao and Holt (2005), Frondel et al. (2008), and Horbach (2008). We measure product eco-innovation using an item such as 'introduced new or improved products or services that are more environmentally friendly than those already on the market', which has been commonly employed in the studies mentioned above and in the European community innovation survey. Two further items were used to measure the significance of the product ecoinnovations within the firms of the sample. For process eco-innovation we used items that indicate the development of eco-innovations that specifically reduce waste and emissions of production processes. Items measured a firms' focus on process eco-innovations that reduced hazardous substances, waste, and wastewater, respectively.

Collaboration variables. The scales for customer and supplier collaboration were used following Doloreux (2004), Zeng et al. (2010) and Nieto and Santamaria (2007). The items used for customer and supplier collaborations were learning, crucial input, and collaboration for eco-innovation. The sample questionnaire used for our study is shown in the appendix. All the items in the seven constructs are based on a seven-point Likert scale for managerial perception. 


\subsection{Sampling}

This study focuses on three manufacturing sectors in China (i.e., automotive, electronics, and textiles), for the following reasons. Firstly, China provides the world largest manufacturing base, manufacturing is its dominant sector and contributes substantially to GDP growth (Feng, Sun \& Zhang, 2010). Secondly, as the most populated country in the world, global awareness for sustainability problems, such as climate change and an excessive use of natural resources, has put a higher onus on the Chinese government. With the U.S. administration pulling back from international responsibility and multilateral agreements, many experts see China as the main actor who could fill the void by becoming the new global environmental leader (Sanger $\&$ Perlez, 2017). China is already at the forefront of renewable energy solutions, indicated by investments of more than $\$ 200$ bn. in clean energy between 2015 and 2016 (BNEF, 2017), and with planned investments of approximately $\$ 360$ billion up to 2020 (Griffiths, 2017). Furthermore, the government announced the development of a National Carbon Emissions Trading System in 2017, which is currently being developed (Duan, Qi, \& Wu, 2018). Thirdly, in addition to these external influences, domestic pressures have significantly increased in the past decade in China (Lin, 2010; Yin \& Zhang, 2012; Faria \& Andersen, 2017). Environmental problems, such as high air and water pollution, have caused a national rethinking among Chinese people and induced a call for more responsible social and environmental business practices (Wang, Sun, Yang, \& Yuan, 2016b; Du, Wang, Brombal, Moriggi, Sharpley \& Pang, 2018). Fourthly, international buying firms sourcing from Chinese suppliers exert pressure on these firms to reduce the environmental and social impact of their products and processes through expected certifications and codes of conduct (Jiang, 2009; Zhu, Sarkis, \& Lai, 2012b; Schleper \& Busse, 2013; Wu, et al., 2016). Under circumstances of fierce competition, this increased attention for environmental efficiency at leading international buying firms oftentimes prompts Chinese supplier firms to ensure the complementarity of their products and processes with the buying firms' requirements (Wu, 2015).

Together, these institutional and relational pressures and the Chinese government's commitment have created an environment for eco-innovations among Chinese firms and has led to strong legitimation of eco-innovative behavior (Qi et al., 2010; Zhu et al., 2012a; Peng $\&$ Liu, 2016). This is also illustrated by the fact that Chinese supplier firms increasingly feel that they have to shift from their low-cost production towards a value capture business model through innovation in order to maintain their global competitiveness (Altenburg, Schmitz, \& Stamm, 2008; Pacheco et al., 2017). 


\subsection{Data collection}

We collected a list of companies registered in the Chinese manufacturing directory and used several filters to shortlist firms based on size, involvement in innovation and eco-innovations, ownership, location, and environmental management systems. In terms of size, we focused on medium- to large-sized firms with more than 100 employees. As not all firms are involved in eco-innovations only those active in the area were targeted in order to increase the validity of our findings. Thus, the firms were screened based on their involvement in eco-innovations, such as product and/or process innovations that are environmentally friendly (i.e., they reduce waste and emissions when compared to existing technologies and products), or energy-saving. We checked for ISO9001, ISO14001 management systems and patenting activity as an indication of eco-innovation activity. The following locations were selected as they provide a distribution of different regions within China which includes more developed coastal regions and less developed inland provinces: the Yangtze River delta; the Pearl River delta; the North region (Beijing, Heilongjiang, Tianjin, Hebei); and the Southwest region (Sichuan, Chongqing, Guizhou, Hunan, Guangxi, Hubei).

To validate the instrument a pilot study was conducted in four firms situated in Zhejiang Province and which satisfied the sampling criteria. Since the respondents are Chinese, the questionnaire was translated into Chinese and for this we used double translation method as suggested by previous studies. One subject expert well acquainted with English and Chinese translated the English version to Chinese, and another similarly experienced expert did the reverse. Based on the above-mentioned criteria, 1,000 companies were randomly shortlisted. Since it is very difficult to collect data from Chinese firms without having a previously established relationship, we hired a data collection agency to collect the data during the period of April 2013 to October 2013. The agency selected was given proper training and one of the authors checked the data collected within several companies of the sample. We concentrated on the automotive, electronics, and textile manufacturing industries since they are highly prone to environmental pollution, and thus to incentives for eco-innovative behavior; about half came from the automotive and automotive components industry. A total of 220 responses was received and included contact respondents' details for further follow up. The response rate of $20.9 \%$ is similar to the previous studies carried out in the Chinese context (e.g., Yam, Lo, Tang, \& Lau, 2011; Liu \& Bai, 2014). The respondents were all mid- to senior-level managers with significant experience in product area and technological expertise. In addition, we categorized CEOs as top management and executives as senior management. We tried to first approach 
CEOs, however, where they were unavailable we contacted senior- or mid-level managers in the enterprise. The majority of the firms are privately owned, have between 100 and 500 employees, and an average time in business of just over 14 years. Characteristics of the respondents are shown in Table 1.

The sample proportion is justified by adherence to the World Economic Forum report (2019) which uses a 60/70/80/90 formula to describe the private sector contribution to the Chinese economy. This means the private sector contributes to $60 \%$ of China's GDP, is responsible for $70 \%$ of innovation, covers $80 \%$ of urban employment, and generates $90 \%$ of China's exports. Given that private enterprises on average are significantly smaller than stateowned enterprises (SOEs), the large majority of firms in our sample are private enterprises with just over $10 \%$ SOEs.

All of the firms have patents, while the majority (more than $80 \%$ ) hold invention patents that represent more significant innovative patents within the Chinese patent system. We tested the non-response bias using the number of design patents and inventions held by the firms in two waves of data collection (150 and 70). No significant difference was found between the two groups (Armstrong \& Overton, 1977).

\section{*** Please insert Table 1 approximately here ***}

\subsection{Analysis}

We used covariance-based structural equation modelling (CB SEM) analysis to test the effect of independent variables on collaboration and dependent variables. CB SEM is a widely used technique to study the influence of underlying factors in a causal relationship between multiple variables when there are more than 200 observations (Chin \& Newsted, 1999).

The measurement model for the seven constructs is presented in Table 2. The item loadings of the measurement models are above 0.5 (Hair, Black, Babin, \& Anderson, 2009), expect one item in the market pressure, supplier collaboration, and customer collaboration constructs. Several studies have indicated that including variables with a factor loading value lower than 0.5 is permitted to satisfy the theoretical rationale and to check to what extent the variable could support the construct (Hair et al., 2009).

\subsection{Reliability and validity}

Reliability of measurement items is tested with Cronbach's alpha and composite reliability. The values are 0.7 and above which denotes that all our items are consistent in measuring the 
constructs (Nunnally \& Bernstein, 1994). As per Schmitt (1996), there is no general acceptable alpha level and Schmitt (ibid) mentions in his article that the instruments with lower alpha value remain useful in some circumstances. In addition, Nunnally \& Bernstein (1996) state the fair acceptable level of alpha value is 0.7 and this is widely used among academics to ensure the reliability of the instrument. AVE values of all our constructs are above 0.5 , similarly composite reliability (CR) values are greater than AVE which explains that all our items share a high proportion of variance in common and sufficiently explain the latent constructs. We used the Fornell \& Larcker (1981) test to determine the discriminant validity of our constructs and, as per the test, all square roots of AVE values of the constructs are larger than the correlation of constructs, as shown in Table 3. This explains sufficient divergent validity of our constructs.

$$
\begin{aligned}
& \text { *** Please insert Table } 2 \text { approximately here } * * * \\
& \text { *** Please insert Table } 3 \text { approximately here } * * *
\end{aligned}
$$

\section{FINDINGS}

We carried out confirmatory factor analysis to test the reliability and validity of the constructs and to evaluate the fit between observed and covariance matrices. Covariance and path fit values, such as chi-square/degree freedom, CFI, and IFI, are above the acceptable levels, as shown in Table 4, and signify good fit of the model. The structural path model is shown in Figure 2, where the fit values are above the suggested threshold values, and the significant paths are highlighted.

We find a number of interesting results based on our path analysis. On the one hand, the path from community pressure to supplier collaboration and process eco-innovations is positive (with 5\% significance level and path coefficients of .14 and .13 respectively). This implies that significant community pressure leads firms to enhance their collaboration with suppliers in order to develop and strengthen process eco-innovations. On the other hand, we do not find regulatory pressure to trigger supplier and/or customer collaboration for process or product eco-innovation, and we do not find an impact of community pressure on customer collaboration for process or product innovation. We do find a positive effect of market pressure on customer collaboration (path coefficient of .18 at 5\% significance level), but this does not have a further effect on product eco-innovation. Contrary to our expectation, market pressure 
has a negative effect on supplier collaboration (path coefficient of -.21 at 5\% significance level). Overall, we find support for $\mathrm{H} 2 \mathrm{a}, \mathrm{H} 3 \mathrm{~b}$, and $\mathrm{H} 5 \mathrm{~b}$.

*** Please insert Figure 2 approximately here ***

\section{DISCUSSION AND IMPLICATIONS}

\subsection{Discussion}

Of the three pressures considered in our study, normative pressures from the local community and civil society groups are the most significant factor that drives Chinese firms to engage in collaboration with suppliers to develop eco-innovations in order to enhance their production processes. We find that regulatory and market pressures, by and large, do not motivate Chinese supplier firms to engage in collaboration for product and/or process oriented eco-innovation. A number of explanations can be provided for these findings.

Firstly, our sample covers manufacturing firms in traditional sectors such as automotive, textiles, and electronics in which the production processes can generate significant environmental impacts on the local environment. To reduce these environmental impacts firms would have to find ways to improve environmental performance of production processes. While environmental regulations are in place in China, there is widespread evidence that complying with regulations only provides limited incentives for local firms to develop innovations, also given the relatively lax local enforcement of regulations, "command without control' as it is so aptly labelled by Lo (2015) and Kostka (2016) (see also Guoyou, et al., 2013 and $\mathrm{Cai}$ and $\mathrm{Li}, 2018$ ). Although attention to environmental issues has become one of the priorities at national level, locally the political and regulatory establishment still tend to favor employment and growth over environmental aspects, part of the reason being that evaluation of local officials has, until recently, been foremostly based on economic performance in their regions (Lo, 2015; Wang, Wijen \& Heugens, 2018). Given that for the majority of suppliers in the automotive, textile, and electronics sectors the local authorities are the main regulatory frame of reference, rather than the central authorities (who directly supervise entities such as larger SOEs), pressures to develop eco-innovations based on regulatory incentives are weak. Recent research indicates that only the most economically advanced localities in China may be willing to sacrifice economic growth for environmental protection, while others follow the mantra 'pollute first, control later' (Pang, Zheng, Shi \& Zhang, 2019). Moreover, the specific 
design of regulation influences innovation. Regulations that set longer-term environmental targets for companies and industries may have a stronger effect on eco-innovation than shorterterm command-and-control regulation (Jänicke \& Lindemann, 2010). Also, a combined and coherent policy mix of market-based, regulatory, and information-based (information disclosure) instruments can trigger innovation responses from firms, but these still tend to be weak in China's environmental governance (Del Rio et al., 2010; Liao, 2018b). Altogether therefore, this may explain why regulatory pressure has a limited effect on Chinese firms' engagement in collaboration for eco-innovation.

The significant impact of communities on supplier collaboration and process innovation shows that Chinese supplier firms are concerned about their reputation, and this often implies reputation within the local community, next to their reputation within the supply chain. Attention to environmental issues by citizens, local communities, and environmental interest groups has risen significantly in China in the past decade or so (Teets, 2013; Zhang, Mol \& He, 2016; Hofman, Moon \& Wu, 2017; Li et al., 2017). Therefore, if various locally active groups, such as local communities, neighborhoods, and environmental interest groups, put pressure on Chinese firms by labelling them as local polluters, companies are more likely to take action and find ways to reduce the environmental impacts of their production processes, e.g., by working with equipment suppliers and knowledge providers. A further reason is that these groups will exert pressure on local officials to take action against these firms (Teets, 2013; Li et al., 2017). So, firms are more likely to respond to these pressures to maintain their local reputation with local interest groups as well as with the local political establishment. These pressures, however, are less likely to trigger a response in product eco-innovation as the environmental impacts associated with products are mostly not local in nature, rather they have more to do with the environmental impact along the whole life-cycle of the product, including the packaging, use-phase and end-of-life phase of the product. This is in line with Xie, Zhu, and Wang (2019) who found a significant effect of manufacturing firms' process ecoinnovations on their green image.

Secondly, we find no significant effect of different institutional pressures on collaboration for product eco-innovation. Although this is in line with Un and Asawaka's (2015) findings on process innovations, for product eco-innovations these findings are rather surprising. We argue that although Chinese supplier firms may engage in product ecoinnovation, they are hesitant to do this in partnership with customers or suppliers. While they may adopt technologies and suggestions from suppliers and customers (also the positive effect from market pressure to customer collaboration indicates some level of engagement with 
customers), the main reason not to engage in innovation collaboration is to minimize the likelihood that product innovation ideas are being copied or taken by outsiders (Zhang, Zeng, Mako, \& Seward, 2009). Opportunistic behavior in supply chain collaboration has been pointed out as a major detrimental factor that can prevent effective partnerships for innovation, and the institutional environment for safeguarding intellectual property rights and contractual obligations plays an important role in reducing opportunistic behavior (Wang, Zhang, Wang, \& Sheng 2016a; Melander, 2018). Although the legal framework for intellectual property protection is advancing in China, it is still not considered effective for most Chinese supplier firms (Zhang et al., 2009; Huang, Geng, \& Wang, 2017).

A third intriguing finding is the dual influence of market pressure on collaboration for eco-innovation. Market pressure is dominantly framed as market pressure for products with enhanced environmental performance, and such demand would be expected to lead to some level of collaboration with customers, as confirmed in our findings. While the collaboration does not lead to product innovation by the firms in our sample, we do not know whether this leads to product innovation by the customers of our sample firms. A number of suppliers in our sample can, as original equipment manufacturers, in fact contribute to the customer's final product innovation. With regard to supplier collaboration we find that higher market pressure has a negative effect on the level of collaboration with suppliers. Reasons for this may be the more exclusive nature of the relationship with the customer and to prevent any opportunistic behavior of suppliers, such as taking some of these innovative ideas to other customers, as the framework for intellectual property protection is too weak to counteract this opportunism.

Overall, we also infer from our study that Chinese supplier firms are more oriented towards process eco-innovation because they may be more concerned with cost saving and supply side factors, next to normative pressure from the community and interest groups. This is in line with Un and Asakawa (2015) who find a significant effect for upstream collaborations (i.e., supplier collaboration) on process innovations, but no effect of downstream collaborations (i.e., customer collaboration) on process innovations. As one potential reason behind this they argue that "the focus of process innovation is primarily on improving manufacturing efficiency and product quality based on how the inputs and components are managed in the production process. The product itself tends to be already determined, and thus, the firm needs to collaborate with partners whose focus is on its production" (Un \& Asakawa, 2015, p. 151). Moreover, in recent years there is more focus on firms developing a 'designed in China' brand, but most of the supplier firms in our sample are focused on providing products based on specifications imposed by customers. 


\subsection{Implications for theory and practice}

A number of theoretical implications can be drawn from our study which is one of the first to apply an integration of institutional theory and relational theory into eco-innovation development in the Chinese context. For our sample of 220 firms in the automotive, textiles, and electronics sectors, we find that community pressure leads to collaboration with suppliers to develop process eco-innovations. We therefore establish the relevance of institutional pressures for eco-innovation collaboration. Our findings for both regulatory and market pressures indicate that more complex underlying components, such as the nature of regulation and the strength of the intellectual property protection regime, need to be taken into account to get a more fine-grained picture of the impact of these pressures on collaboration for ecoinnovation. We provide some further insight into how these institutional pressures impact differently upon product eco-innovation and process eco-innovation, this is an important finding that needs to be taken forward in further research. As indicated in a broader study on innovation, the collaboration and innovation mechanisms for these different types of innovation seem to be significantly different (Un \& Asakawa, 2015). Moreover, with the trend moving from original equipment manufacturers (OEM) towards increasing original design manufacturers (ODM) and own brand manufacturers (OBM) in China increasing attention for product innovation relative to process innovation may be expected (Altenburg et al., 2008; Chen, Wei, \& Hu, 2016).

Our research has implications for policy makers and managers. With environmental issues now a priority for the Chinese government, the design of effective regulatory pressures is a critical issue for policy makers. Enhancing the effectiveness of regulations to stimulate eco-innovations in firms and ensuring implementation from the central level to the local level needs to be a key concern. Our findings indicate that the current regulatory pressures do not provide incentives for Chinese supplier firms to engage in collaboration for eco-innovation. Developing more fine-tuned regulatory incentives to develop eco-innovations is therefore needed, together with significant local support for companies to engage in eco-innovations. Moreover, our findings indicate the importance of other stakeholders such as communities and NGOs to pressure local companies towards eco-innovation. Providing scope and support for these stakeholders to continue to engage in monitoring the behavior of firms can be an effective tool to enhance environmental performance and eco-innovations in local firms.

Managers can also draw some lessons from our research. Firstly, engaging with suppliers can be an effective way to develop process eco-innovations and potentially improve 
both environmental and economic performance. However, the path towards developing ecoinnovations and enhancing environmental performance will take time and effort. Working together with various stakeholders, such as suppliers and potentially local stakeholders, helps to enhance reputation and potentially accelerate the change process towards becoming a more environment-friendly supplier. Supply chain management therefore needs to combine aspects of relational governance and trust building with suppliers and customers next to the more traditional contractual governance.

Finally, we believe our research is also of relevance for business schools and the teaching of supply chain management. Supply chain collaboration for eco-innovations cannot be based on a one-size-fits-all approach. Our research clearly indicates that the Chinese context has a specific influence on the nature of collaboration and the incentives for eco-innovations. Teaching in business schools on supply chain management needs to consider different approaches when discussing developed economies and emerging economies. The findings from our research, in combination with research from, for example, Arranz et al. (2019), Guoyou et al (2013), Jabbour et al., (2015), Liao (2018a), Silvestre (2014), and Zeng et al., (2017), can provide the building stones for a curriculum in supply chain management that is sensitive to the contextual factors in emerging economies which influence relational governance and eco-innovations within the supply chain.

\subsection{Limitations and future research}

The current research has a number of limitations that also provide suggestions for future research. The present study captures the effect of collaboration from the firm's perspective and not from the full supply chain. To gain a better understanding of supply chain collaboration and eco-innovations, future research can capture the dyadic and triadic effect with the views on collaboration benefits and the eco-innovation outcomes from both suppliers and customers. Furthermore, we did not study the effect of more specific characteristics of firms, such as ODM and/or OBM orientation, supply chain governance, and corporate governance, on supply chain collaboration and eco-innovations. This is a possible way forward to identify factors that affect customer collaboration for product eco-innovations.

Furthermore, this study does not take into account further informal institutional variables, such as guanxi, defined as "the cultural characteristic of interpersonal relationship ties that affect firms' business decisions and behaviours and collaborations between buyers and suppliers" (Geng, Mansouri, Aktas, \& Yen, 2019, p. 2). Previous studies have emphasized guanxi's importance in Asian emerging economies and in China (Lee, Ooi, Chong, \& Lin, 
2015; Yen \& Abosag, 2016; Geng et al., 2019). Particularly, Geng et al. (2019) find a significant moderating role of guanxi on institutional pressures (particularly community pressure) that impacts the adoption of environmental practices in China. Future research on the influence of institutional pressures on eco-innovations through means of supply chain collaboration could build on these results.

Lastly, two recent studies investigate further potential factors in eco-innovations: Arranz et al. (2019) emphasize the influence of regional innovation systems as a driver for ecoinnovations, whereas Pan, Chen, Sinha, and Dong (2020) show the non-monolithic character of state-ownership which suggests a curvilinear influence on eco-innovations. Thus, besides the importance of capabilities and resources, regulation and stakeholder pressures, these studies provide interesting pathways for future research on eco-innovations. However, this study neglected the potential impact of these geographical factors as well as state-ownership, and these are relevant aspects to include in future research.

\section{CONCLUSION}

Using an institutional and relational theory perspective, this study develops a conceptual model to identify the influence of three major institutional drivers including market, community, and regulatory pressures on upstream as well as downstream supply chain collaborations and their eco-innovation outcomes. Based on samples from three Chinese manufacturing industries, the study identifies market pressure and community pressure as the major drivers for Chinese firms to collaborate with their suppliers. Supplier collaborations induce firms to become involved in process eco-innovation. Interestingly our study shows that Chinese firms are not eager to collaborate with their customers to develop product eco-innovations and regulatory pressure has no influence on customer or supplier collaboration. The current study can be further extended by exploring more fine-grained institutional factors and pressures, more specific aspects of relational governance, and the impact of these on product eco-innovations and process eco-innovations. 


\section{REFERENCES}

Adams, R., Jeanrenaud, S., Bessant, J., Denyer, D., \& Overy, P., (2016). Sustainabilityoriented innovation: a systematic review. International Journal of Management Reviews, $18(2), 180-205$.

Altenburg, T., Schmitz, H., \& Stamm, A. (2008). Breakthrough? China's and India's transition from production to innovation. World Development, 36(2), 325-344.

Amui, L. B. L., Jabbour, C. J. C., de Sousa Jabbour, A. B. L., \& Kannan, D. (2018). Sustainability as a dynamic organizational capability: a systematic review and a future agenda toward a sustainable transition. Journal of Cleaner Production, 142(1), 308-322.

Ardito, L., Petruzzelli, A. M., Pascucci, F., \& Peruffo, E. (2019). Inter-firm R\&D collaborations and green innovation value: The role of family firms' involvement and the moderating effects of proximity dimensions. Business Strategy and the Environment, 28(1), 185-197.

Armstrong, J. S., \& Overton, T. S. (1977). Estimating nonresponse bias in mail surveys. Journal of Marketing Research, 14(3), 396-402.

Arranz, N., Arroyabe, C. F., \& de Arroyabe, C. J. F. (2019). The effect of regional factors in the development of eco-innovations in the firm. Business Strategy and the Environment, 28(7), 1406-1415.

Arundel, A., \& Kemp, R. (2009). Measuring eco-innovation. UNU-MERIT Working Paper Series 2009-017, United Nations University - Maastricht Economic and Social Research and Training Centre on Innovation and Technology.

Bansal, P. (2005). Evolving sustainably: A longitudinal study of corporate sustainable development. Strategic Management Journal, 26(3), 197-218.

Bansal, P., \& Roth, K. (2000). Why companies go green: A model of ecological responsiveness. Academy of Management Journal, 43(4), 717-736.

Bergkvist, L and Rossiter, J.R (2007). The predictive validity of multiple-item versus singleitem measures of the same constructs. Journal of Marketing Research, 44(2): 175-184.

Berrone, P., Fosfuri, A., Gelabert, L., \& Gomez-Mejia, L.R. (2013). Necessity as the mother of 'green' inventions: institutional pressures and environmental innovations. Strategic Management Journal, 34(8), 891-909.

Blome, C., Schoenherr, T., Kaesser, M. (2013). Ambidextrous governance in supply chains: the impact on innovation and cost performance. Journal of Supply Chain Management, 49(4), 59-80.

BNEF (Bloomberg New Energy Finance) (2017). Record \$30bn year for offshore wind but overall investment down. Retrieved from https://about.bnef.com/blog/record-30bn-yearoffshore-wind-overall-investment/. Last accessed on 02 February 2019.

Bossle, M. B., de Barcellos, M. D., Vieira, L. M., Sauvée, L. (2016). The drivers for adoption of eco-innovation. Journal of Cleaner Production, 113, 861-872 .

Busse, C., Schleper, M. C., Niu, M., \& Wagner, S. M. (2016). Supplier development for sustainability: contextual barriers in global supply chains. International Journal of Physical Distribution and Logistics Management, 46(5), 442-468.

Busse, C., Schleper, M. C., Weilenmann, J., \& Wagner, S. M. (2017). Extending the supply chain visibility boundary: Utilizing stakeholders for identifying supply chain sustainability risks. International Journal of Physical Distribution and Logistics Management, 47(1), 1840.

Cai, W., \& Li, G. (2018). The drivers of eco-innovation and its impact on performance: evidence from China. Journal of Cleaner Production, 176, 110-118.

Cai, W., \& Zhou, X. (2014). On the drivers of eco-innovation: empirical evidence from China. Journal of Cleaner Production, 79, 239-248. 
Cainelli, G., De Marchi, V., \& Grandinetti, R. (2015). Does the development of environmental innovation require different resources? Evidence from Spanish manufacturing firms. Journal of Cleaner Production, 94, 211-220.

Campbell, J. L. (2007). Why would corporations behave in socially responsible ways? An institutional theory of corporate social responsibility. Academy of Management Review, 32(3), 946-967.

Chen, D., Wei, W., \& Hu, D. (2016). Survival strategy of OEM companies: a case study of the Chinese toy industry. International Journal of Operations \& Product Management, 36(9), 1065-1088.

Chen, J., Cheng, J., \& Dai, S. (2017a). Regional eco-innovation in China: An analysis of ecoinnovation levels and influencing factors. Journal of Cleaner Production, 153, 1-14.

Chen, L., Zhao, X., Tang, O., Price, L., Zhang, S., \& Zhu, W. (2017b). Supply chain collaboration for sustainability: A literature review and future research agenda. International Journal of Production Economics, 194(C), 73-87.

Cheung, D. K. K., Welford, R. J., \& Hills, P. R. (2009). CSR and the environment: business supply chain partnerships in Hong Kong \& PRDR, China. Business Strategy and the Environment, 16(5), 250-263.

Chin, W. W., \& Newsted, P. R. (1999). Structural Equation Modeling analysis with small samples using Partial Least Squares. In: Rick Hoyle (ed.), Statistical Strategies for Small Sample Research. Sage, Thousand Oaks, CA, 307-341.

Christmann P. (2004). Multinational companies and the natural environment: Determinants of global environmental policy standardization. Academy of Management Journal, 47(5), 747760 .

CIS (Community Innovation Survey) (2012). Retrieved from: https://ec.europa.eu/eurostat/documents/203647/203701/Harmonised+survey+questionnair e+2012/164dfdfd-7f97-4b98-b7b5-80d4e32e73ee. Last accessed on 29 January 2020.

Colwell, S. R., \& Joshi, A. W. (2013). Corporate ecological responsiveness: antecedent effects of institutional pressure and top management commitment and their impact on organizational performance. Business Strategy and the Environment, 22(2), 73-91.

Costantini, V., Crespi, F., Marin, G., \& Paglialunga, E. (2017). Eco-innovation, sustainable supply chains and environmental performance in European industries. Journal of Cleaner Production, 155, 141-154.

Dai, J., Cantor, D. E., \& Montabon, F. L. (2015). How environmental management competitive pressure affects a focal firm's environmental innovation activities: a green supply chain perspective. Journal of Business Logistics, 36(3), 242-259.

Danese, P., Lion, A., \& Vinelli, A. (2019). Drivers and enablers of supplier sustainability practices: a survey-based analysis. International Journal of Production Research, 57(7), 2034-2056.

Dangelico, R. M. (2016). Green product innovation: Where we are and where we are going. Business Strategy and the Environment, 25(8), 560-576.

Dangelico, R. M., Pontrandolfo P., \& Pujari, D. (2013) Developing sustainable new products in the textile and upholstered furniture industries: Role of external integrative capabilities. Journal of Product Innovation Management, 30(4), 642-658.

Dangelico, R. M., Pujari, D., \& Pontrandolfo P. (2017). Green product innovation in manufacturing firms: A sustainability-oriented dynamic capability perspective. Business Strategy and the Environment, 26(4), 490-506.

Darnall, N., Potoski, M., \& Prakash, A. (2010). Sponsorship matters: assessing business participation in government- and industry-sponsored voluntary environmental programs. Journal of Public Administration Research and Theory, 20(2), 283-307. 
Delmas, M., \& Toffel, M. (2004). Stakeholders and environmental management practices: an institutional framework. Business Strategy and the Environment, 13(4), 209-222.

Del Río, P., Carrillo-Hermosilla, J., \& Könnölä, T. (2010). Policy strategies to promote ecoinnovation. Journal of Industrial Ecology, 14(4), 541-557.

Del Río, P., Peñasco, C., \& Romero-Jordán, D. (2015). Distinctive features of environmental innovators: an econometric analysis. Business Strategy and the Environment, 24(6), 361385.

De Marchi, V. (2012). Environmental innovation and R\&D cooperation: Empirical evidence from Spanish manufacturing firms. Research Policy, 41(3), 614-623.

De Marchi, V., \& Grandinetti, R. (2013). Knowledge strategies for environmental innovations: the case of Italian manufacturing firms. Journal of Knowledge Management, 17(4), 569582.

Dias Angelo, F., Jabbour, C. J. C., \& Vasconcellos Galina, S. (2012). Environmental innovation: in search of a meaning. World Journal of Entrepreneurship, Management and Sustainable Development, 8(2/3), 113-121.

DiMaggio, P. J., \& Powell, W.W. (1983). The iron cage revisited: institutional isomorphism and collective rationality in organizational fields. American Sociological Review, 48(2), 147-160.

Doloreux, D. (2004) Innovative networks in core manufacturing firms: Evidence from the metropolitan area of Ottawa. European Planning Studies. 12(2), 173-189.

Doran, J., \& Ryan, G. (2012). Regulation and firm perception, eco-innovation and firm performance. European Journal of Innovation Management, 15(4), 421-441.

Doran, J., \& Ryan, G. (2016). The importance of the diverse drivers and types of environmental innovation for firm performance. Business Strategy and the Environment, 25(2), 102-119.

Du, Y., Wang, X., Brombal, D., Moriggi, A., Sharpley, A., \& Pang, S. (2018). Changes in Environmental awareness and its connection to local environmental management in water conservation zones: The case of Beijing, China. Sustainability, 10(6), 2087-2111.

Duan, M., Qi, S., \& Wu, L. (2018). Designing China's national carbon emissions trading system in a transitional period, Climate Policy, 18(1), 1-6.

Driessen, P. H., Hillebrand, B., Kok, R. A. W., \& Verhallen, T. M. M. (2013). Green new product development: The pivotal role of product greenness. IEEE Transactions on Engineering Management, 60(2), 315-326.

Dyer, J. H., \& Singh, H. (1998). The relational view: cooperative strategy and sources of interorganizational competitive advantage. Academy of Management Review, 23(4), 660 679.

Faria, L. G. D., \& Andersen, M. M. (2017). Sectoral patterns versus firm-level heterogeneity The dynamics of eco-innovation strategies in the automotive sector. Technological Forecasting \& Social Change, 117, 266-281.

Feng, T., Sun, L., \& Zhang, Y. (2010). The effects of customer and supplier involvement on competitive advantage: An empirical study in China. Industrial Marketing Management 39(8), 1384-1394.

Fernando, Y., Jabbour, C. J. C., \& Wah, W.-X. (2019). Pursuing green growth in technology firms through the connections between environmental innovation and sustainable business performance: Does service capability matter? Resources, Conservation and Recycling, 141, $8-20$.

Foerstl, K., Reuter, C., Hartmann, E., \& Blome, C. (2010). Managing supplier sustainabilityrisks in a dynamically changing environment: sustainable supplier managementin the chemical industry. Journal of Purchasing and Supply Management, 16 (2), 118-130. 
Foray, D., \& Grübler, A. (1996). Technology and the environment: an overview. Technological Forecasting and Social Change, 53(1), 3-13.

Fornell, C., \& Larcker, D. F. (1981). Evaluating structural equation models with unobservable variables and measurement error. Journal of Marketing Research, 18(1), 39-50.

Frondel, M., Horbach, J., \& Rennings, K. (2008). What triggers environmental management and innovation? Empirical evidence for Germany. Ecological Economics, 66(1), 153-160.

Fussler, C., \& James, P. (1996). Eco-innovation: A Breakthrough Discipline for Innovation and Sustainability. Pitman Publishing, London.

Gao, D., Xu, Z., Ruan, Y.Z., \& Lu, H. (2017). From a systematic literature review to integrated definition for sustainable supply chain innovation (SSCI). Journal of Cleaner Production, $142,1518-1538$.

Garrone, P., Grilli, L., \& Mrkajic, B (2018). The role of institutional pressures in the introduction of energy-efficiency innovations. Business Strategy and the Environment, 27(8), 1245-1257.

Geffen, C., \& Rothenberg, S. (2000. Suppliers and environmental innovation: The automotive paint process. International Journal of Operations \& Production Management, 20(2), 166186.

Geng, R., Mansouri, A., Aktas, E., \& Yen, D. (2019). An empirical study of green supplier collaboration in the Chinese manufacturing sector: the double-edged sword effect of guanxi. Supply Chain Management, ahead-of-print, https://doi.org/10.1108/SCM-03-2019-0135.

Giménez Thomsen, C., \& Tachizawa, E. M. (2012). Extending sustainability to suppliers: A systematic literature review. Supply Chain Management: An International Journal, 17(5), 531-543.

Glover, J. L., Champion D., Daniels, K. J., \& Dainty, A. J. D. (2014). An Institutional Theory perspective on sustainable practices across the dairy supply chain. International Journal of Production Economics, 152, 102-111.

Gmelin, H., \& Seuring, S. (2014). Determinants of a sustainable new product development. Journal for Cleaner Production, 69, 1-9.

Goebel, P., Reuter, C., Pibernik, R., Sichtmann, C., \& Bals, L. (2018). Purchasing managers' willingness to pay for attributes that constitute sustainability. Journal of Operations Management, 62, 44-58.

Goodman, J., Korsunova, A., \& Halme, M. (2017). Our collaborative future: activities and roles of stakeholders in sustainability-oriented innovation. Business Strategy and the Environment, 26(6), 731-753.

Griffiths, J. (2017). Can China pick up US slack on climate change? CNN.com (29 March 2017). Retrieved from: https://edition.cnn.com/2017/03/29/asia/china-trump-climatechange/index.html. Last accessed on 02 February 2019.

Guoyou, Q., Saixing, Z., Chiming, T., Haitao, Y., \& Hailiang, Z. (2013). Stakeholders' influences on corporate green innovation strategy: A case study of manufacturing firms in China. Corporate Social Responsibility and Environmental Management, 20(1), 1-14.

Hair, J. F., Black, W. C., Babin, B. J., \& Anderson, R. E. (2009). Multivariate Data Analysis ( $7^{\text {th }}$ edition). Prentice Hall, New Jersey.

Hajmohammad, S., \& Vachon, S. (2016). Mitigation, avoidance, or acceptance? Managing Supplier Sustainability Risk. Journal of Supply Chain Management, 52(2), 48-65.

Hall, J. (2000). Environmental supply chain dynamics. Journal of Cleaner Production, 8, 455471.

Hansen, E. G., \& Klewitz, J. (2013). The role of an SME's green strategy in public-private eco-innovation initiatives: the case of Ecoprofit. Journal of Small Business and Entrepreneurship 25(4), 451-478. 
Hart, S. L., \& Dowell, G. (2011). A Natural-Recource-Based View of the firm - Fifteen years after. Journal of Management, 37(5), 1464-1479.

Hartmann, J., \& Moeller, S. (2014). Chain liability in multitier supply chains? Responsibility attributions for unsustainable supplier behavior. Journal of Operations Management, 32(5), 281-294.

He, X. \& Jiang, S. (2019). Does gender diversity matter for green innovation? Business Strategy and the Environment, 28(7), 1341-1356.

Hoejmose S.U., Grosvold J, Millington A (2014). The effect of institutional pressure on cooperative and coercive green supply chain practices. Journal of Purchasing and Supply Management, 20(4): 215-224.

Hofman, P. S., Moon, J., \& Wu, B. (2017). Corporate social responsibility under authoritarian capitalism: dynamics and prospects of state-led and society-driven CSR. Business \& Society, 56(5), 651-671.

Hofmann, H., Busse, C., Bode, C., \& Henke, M. (2014). Sustainability-related supply chain risks: Conceptualization and management. Business Strategy and the Environment, 23(3), 160-172.

Hollos, D., Blome, C., \& Foerstl, K. (2012). Does sustainable supplier co-operation affect performance? Examining implications for the Triple Bottom Line. International Journal of Production Research, 50(11), 2968-2986.

Horbach, J. (2008). Determinants of environmental innovation - new evidence from German panel data sources. Research Policy, 37(1), 163-173.

Horbach, J., Rammer, C., \& Rennings, K. (2012). Determinants of eco-innovations by type of environmental impact - The role of regulatory push/pull, technology push and market pull. Ecological Economics, 78, 112-122.

Huang, K. G., Geng, X. \& Wang, H. (2017). Institutional regime shift in intellectual property rights and innovation strategies of firms in China. Organization Science, 28(2), 355-77.

Hsu, I. C., (2008). Knowledge sharing practice as a facilitating factor for improving organizational performance through human capital: a preliminary test. Expert Systems with Applications, 35(3), 1316-1326.

Jabbour, C. J. C., Neto, A. S., Gobbo Jr., J. A., de Souza Ribeiro, M., \& de Sousa Jabbour, A. B. L. (2015). Eco-innovations in more sustainable supply chains for a low-carbon economy: A multiple case study of human critical success factors in Brazilian leading companies. International Journal of Production Economics, 164, 245-257.

Jänicke, M., \& Lindemann, S. (2010). Governing environmental innovations. Environmental Politics, 19(1), 127-141.

Jiang, B. (2009). The effects of interorganizational governance on supplier's compliance with SCC: An empirical examination of compliant and non-compliant suppliers. Journal of Operations Management, 27(4), 267-280.

Kammerer, D. (2009). The effects of customer benefit and regulation on environmental product innovation. Empirical evidence from appliance manufacturers in Germany. Ecological Economics, 68 (8/9), 2285-2295.

Kesidou, E., \& Demirel, P. (2012). On the drivers of eco-innovations: empirical evidence from the UK. Research Policy, 41(5), 862-870.

Kostka, G. (2016). Command without control: the case of China's environmental target system. Regulation and Governance, 10, 58-74.

Klewitz, J., \& Hansen, G. (2014). Sustainability-oriented innovation of SMEs: a systematic review. Journal of Cleaner Production, 65, 57-75.

Large, R. O., \& Giménez Thomsen, C. (2011). Drivers of green supply management performance: Evidence from Germany. Journal of Purchasing and Supply Management, 17(3), 176-184. 
Laroche, M., Bergeron, J., \& Barbaro-Forleo, G. (2001). Targeting consumers who are willing to pay more for environmentally friendly products. Journal of Consumer Marketing, $18(6), 503-520$.

Lee, S. Y. (2008). Drivers for the participation of small and medium-sized suppliers in green supply chain initiatives. Supply Chain Management: An International Journal, 13(3), 185198.

Lee, K.-H., \& Kim, J. W. (2011). Integrating suppliers into green product innovation development: an empirical case study in the semiconductor industry. Business Strategy and the Environment, 20(8), 527-538.

Lee, V.-H., Ooi, K.-B., Chong, A. Y.-L., \& Lin, B. (2015). A structural analysis of greening the supplier, environmental performance and competitive advantage. Production Planning \& Control, 26(2), 16-130.

Lengnick-Hall, C. A. (1992). Innovation and competitive advantage: What we know and what we need to learn. Journal of Management, 18(2), 399-429.

Lewis, G. J., Harvey, B. (2001). Perceived environmental uncertainty: The extension of Miller's scale to the natural environment. Journal of Management Studies, 38(2), 201-234.

Lewis, K. V., Cassells, S., \& Roxas, H. (2015). SMEs and the potential for a collaborative path to environmental responsibility. Business Strategy and the Environment, 24(8),750-764.

Lewis, M., Brandon-Jones, A., Slack, N., \& Howard, M. (2010). Competing through operations and supply-the role of classic and extended resource based advantage. International Journal of Operations and Production Management, 30(10), 1032-1058.

Li, G., He, Q., Shao, S., \& Cao, J. (2017) Environmental non-governmental organizations and urban environmental governance: evidence from China. Journal of Environmental Management, 206, 1296-1307.

Li, J., Chen, D., \& Shapiro, D. M. (2010). Product innovation in emerging economies: The role of foreign knowledge access channels and internal efforts in Chinese firms. Management and Organization Review, 6(2), 243-266.

Liao, Z. (2018a). Institutional pressure, knowledge acquisition and a firm's environmental innovation. Business Strategy and the Environment, 27(7), 849-857.

Liao, Z. (2018b). Content analysis of China's environmental policy instruments on promoting firms' environmental innovation. Environmental Science and Policy, 88, 46-51.

Lin, L. W. (2010). Corporate social responsibility in China: window dressing or structural change?. Berkeley Journal of International Law, 28(1), 64-100.

Liu, X., Dai, H., \& Cheng, P. (2011). Drivers of integrated environmental innovation and impact on company competiveness: evidence from 18 Chinese firms. International Journal of Technology and Globalisation, 5(3/4), 255-280.

Liu, X. B., Yang, J., Qu, S. X., Wang, L. N., Shishime, T., \& Bao, C. K. (2012). Sustainable production: Practices and determinant factors of green supply chain management of Chinese companies. Business Strategy and the Environment, 21(1), 1-16.

Liu, Y., \& Bai, Y. (2014). An exploration of firms' awareness and behavior of developingcircular economy: An empirical research in China. Resources, Conservation and Recycling, 87, 145-152.

Lo, K. (2015). How authoritarian is the environmental governance of China? Environmental Science \& Policy, 54, 152-159.

Loureiro, M. L. \& Lotade, J. (2005). Do fair trade and eco-labels in coffee wake up the consumer conscience? Ecological Economics, 53, 129-138.

Malik, K., \& Wei, J. (2011). How external partnering enhances innovation: Evidence from Chinese technology-based SMEs. Technology Analysis and Strategic Management, 23(4), 401-413. 
Marquis, C., Zhang, J., \& Zhou, Y. (2011). Regulatory uncertainty and corporate responses to environmental protection in China. California Management Review, 54(1), 39-63

Melander, L. (2017). Achieving sustainable development by collaborating in green product innovation. Business Strategy and the Environment, 26(8), 1095-1109.

Melander, L. (2018). Customer and supplier collaboration in green product innovation: external and internal capabilities. Business Strategy and the Environment, 27(6), 677-693.

Melander, L., \& Pazirandeh, A. (2019). Collaboration beyond the supply network for green innovation: insight from 11 cases. Supply Chain Management, 24(4), 509-523.

Meyer, W., \& Rowan, B. (1977). Institutionalized organizations: formal structure as myth and ceremony. American Journal of Sociology, 83(2), 340-363.

Miller, D. (1988). Relating porters business strategies to environments and structure: analysis and performance implications. Academy of Management Journal, 31(2), 280-308.

Mülling Neutzling, D., Land, A., Seuring, S., \& do Nascimento, L. F. M. (2018). Linking sustainability-oriented innovation to supply chain relationship integration. Journal of Cleaner Production, 172, 3448-3458.

Neto, A. S., Jabbour, C. J. C., \& de Sousa Jabbour, A. B. L. (2014). Green training supporting eco-innovation in three Brazilian companies: practices and levels of integration. Industrial and Commercial Training, 46(7), 387-392.

Nieto, M. J., \& Santamaria, L. (2007). The importance of diverse collaborative networks for the novelty of product innovation. Technovation 27(6-7), 367-377.

Nunnally, J. C., \& Bernstein, I. H. (1994). Psychometric Theory. McGraw-Hill, New York.

Ociepa-Kubicka, A., \& Pachura, P. (2017). Eco-innovations in the functioning of companies. Environmental Research, 156, 284-290.

OECD (2009). Eco-Innovation in Industry - Enabling Green Growth. OECD publishing, Paris.

Oglethorpe, D. (2010) Optimising economic, environmental, and social objectives: a goalprogramming approach in the food sector. Environment and Planning A, 42(5), 1239-1254.

Oliver, C. (1991). Strategic responses to institutional processes. Academy of Management Review, 16(1), 145-179.

Pacheco, D. A. J., ten Caten, C. S., Jung, C. E., Ribeiro, J. L. D., Navas, H. V. G., \& CruzMachado, V. A. (2017). Eco-innovation determinants in manufacturing SMEs: Systematic review and research directions. Journal of Cleaner Production, 142, 2277-2287.

Pan, X., Chen, X., Sinha, P., \& Dong, N. (2020). Are firms with state ownership greener? An institutional complexity view. Business Strategy and the Environment, 29(1), 197-211.

Pang, R., Zheng, D., Shi, M. J., \& Zhang, X. I. (2019). Pollute first, control later? Exploring the economic threshold of effective environmental regulation in China's context. Journal of Environmental Management, 248, 109275, 1-13.

Parmigiani, A., Klassen, R. D., \& Russo, M. V. (2011). Efficiency meets accountability: Performance implications of supply chain configuration, control, and capabilities. Journal of Operations Management, 29(3), 212-223.

Paulraj, A., Jayaraman, V., \& Blome, C. (2014). Complementarity effect of governance mechanisms on environmental collaboration: does it exist? International Journal of Production Research, 52(23), 6989-7006.

Pavlovich, K., \& Akoorie, M. (2010). Innovation, sustainability and regional development: the Nelson/Marlborough seafood cluster, New Zealand. Business Strategy and the Environment, 19(6), 377-386.

Peng, X., \& Liu, Y. (2016). Behind eco-innovation: Managerial environmental awareness and external resource acquisition. Journal of Cleaner Production, 139, 347-360.

Qi, G. Y., Shen, L. Y., Zeng, S. X., Jorge, \& O. J. (2010). The drivers for contractors' green innovation: an industry perspective. Journal of Cleaner Production, 18(14), 1358-1365. 
Ramanathan, U., Bentley, Y., \& Pang, G. (2014). The role of collaboration in the UK green supply chains: an exploratory study of the perspectives of suppliers, logistics and retailers. Journal of Cleaner Production, 70, 231-241.

Rao, P., \& Holt, D. (2005). Do green supply chains lead to competitiveness and economic performance? International Journal of Operations \& Production Management, 25(9), 898916.

Rennings, K. (2000). Redefining innovation - eco-innovation research and the contribution from ecological economics. Ecological Economics 32(2), 319-332.

Roscoe, S., Cousins, P. D., \& Lamming, R. C. (2016). Developing eco-innovations: a threestage typology of supply networks. Journal of Cleaner Production, 112, 1948-1959.

Salomon, R. M., \& Shaver, J. M. (2005). Learning by exporting: New insights from examining firm innovation. Journal of Economics and Management Strategy, 14(2), 431-460.

Sanger, D. E., \& Perlez, J. (2017). Trump hands the Chinese a gift: The chance for global leadership. The New York Times (1 June 2017). Retrieved from: https://www.nytimes.com/2017/06/01/us/politics/climate-accord-trump-china-globalleadership.html?_r=0. Last accessed on 20 January 2020.

Schleper, M. C., \& Busse, C. (2013). Towards a standardized supplier code of ethics: development of a design concept based on diffusion of innovation theory. Logistics Research, 6(4), 187-216.

Schmitt, N. (1996). Uses and abuses of coefficient alpha. Psychological Assessment, 8(4), 350353.

Scott, W. R. (1994). Institutions and Organizations. Toward a Theoretical Synthesis. In: Scott, W.R. \& Meyer, J.W. (Eds.), Institutional Environments and Organizations. Structural Complexity and Individualism, p. 55-80. Sage, Thousand Oaks, CA.

Scott, W. R. (2001). Institutions and Organizations. Sage, Thousand Oaks, CA.

Sharfman, M. P., Gray, B., \& Yan, A. (1991). The context of interorganizational collaboration in the garment industry: An institutional perspective. The Journal of Applied Behavioral Science, 27(2), 181-208.

Sharma, S., \& Henriques I. (2005). Stakeholder influences on sustainability practices in the Canadian forest products industry. Strategic Management Journal, 26(2), 159-180.

Sharma, S., \& Vredenburg, H. (1998). Proactive corporate environmental strategy and the development of competitively valuable organizational capabilities. Strategic Management Journal, 19(8), 729-753.

Silvestre, B. S. (2014). A hard nut to crack! Implementing supply chain sustainability in an emerging economy. Journal of Cleaner Production, 96, 171-181.

Tachizawa, E., Gimenez, C., \& Sierra, V. (2015). Green supply chain management approaches: drivers and performance implications. International Journal of Operations \& Production Management, 35(11), 1546-1566.

Tan, C. L., \& Tracey, M. (2007). Collaborative new product development environments: implications for supply chain management. Journal of Supply Chain Management, 43(3), $2-15$.

Tang, M., Walsh, G. S., Lerner, D. A., Fitza, M., \& Li, Q. (2018). Green innovation, managerial concern and firm performance: an empirical study. Business Strategy and the Environment, 27(1), 39-51.

Teets, J. C. (2013). Let many civil societies bloom: the rise of consultative authoritarianism in China. The China Quarterly, 213, 19-38.

Triguero, A., Moreno-Mondéjar, L., \& Davia, M. A. (2013). Drivers of different types of ecoinnovation in European SMEs. Ecological Economics, 92, 25-33. 
Tsai, K.-H., \& Liao, Y.-C. (2017). Innovation capacity and the implementation of ecoinnovation: Toward a contingency perspective. Business Strategy and the Environment, 26(7), 1000-1013.

Un, C. A., \& Asakawa, K. (2015). Types of R\&D collaborations and process innovation: The benefit of collaborating upstream in the knowledge chain. The Journal of Product Innovation Management, 32(1), 138-153.

Vachon S. (2007). Green supply chain practices and the selection of environmental technologies. International Journal of Production Research, 45(18-19), 4357-4379.

Vachon, S., \& Klassen, R. D. (2006). Extending green practices across the supply chain: the impact of upstream and downstream integration. International Journal of Operations and Production Management, 2(7), 795-821.

Vachon, S., \& Klassen, R. D. (2008). Environmental management and manufacturing performance: the role of collaboration in the supply chain. International Journal of Production Economics, 111(2), 299-315.

Van Rooij, B., Stern, R. E., \& Fürst, K. (2016). The authoritarian logic of regulatory pluralism: Understanding China's new environmental actors. Regulation \& Governance, 10, 3-13.

Wagner, M. (2007). On the relationship between environmental management, environmental innovation and patenting: Evidence from German manufacturing firms. Research Policy, 36(10), 1587-1602.

Wagner, M., \& Llerena, P. (2011). Eco-Innovation through integration, regulation and cooperation: Comparative insights from case studies in three manufacturing sectors. Industry and Innovation, 18(8), 747-764.

Wang, M., Zhang, Q., Wang, Y., \& Sheng, S. (2016a). Governing local supplier opportunism in China: Moderating role of institutional forces. Journal of Operations Management, 46: 84-94.

Wang, R., Wijen, F., \& Heugens, P. P. M. A. R. (2018). Government's green grip: Multifaceted state influence on corporate environmental actions in China. Strategic Management Journal, 39(2), 403-428.

Wang, S., Li, J., \& Zhao, D. (2017). Institutional pressures and environmental management practices: The moderating effects of environmental commitment and resource availability. Business Strategy and the Environment, 27(1), 52-69.

Wang, Y., Sun, M., Yang, X., \& Yuan, X. (2016b). Public awareness and willingness to pay for tackling smog pollution in China: a case study. Journal of Cleaner Production, 112(2), 1627-1634.

World Economic Forum report (2019). Explained, the role of China's state-owned companies. https://www.weforum.org/agenda/2019/05/why-chinas-state-owned-companies-still-havea-key-role-to-play/, last accessed on 28 March 2020.

$\mathrm{Wu}, \mathrm{J}$. (2015). Differentiated customer pressures and environmental policies in China. Business Strategy and the Environment, 24(3), 175-189.

Wu, K.-J., Liao, C.-J., Chen, C.-C., Lin, Y., \& Tsai, C. F. M. (2016). Exploring eco-innovation in dynamic organizational capability under incomplete information in the Taiwanese lighting industry. International Journal of Production Economics, 181, 419-440.

Xi, Jinping (2017). Full text of Xi Jinping's report at 19th CPC National Congress, China Daily, 4 November 2017. Retrieved from http://www.chinadaily.com.cn/china/19thcpc nationalcongress/2017-11/04/content_34115212.htm. Last accessed on 31 March 2020.

Xie, X., Zhu, Q., \& Wang, R. (2019). Turning green subsidies into sustainability: How green process innovation improves firms' green image. Business Strategy and the Environment, 28(7), 1416-1433. 
Yalabik, B., \& Fairchild, R. J. (2011). Customer, regulatory, and competitive pressure as drivers of environmental innovation. International Journal of Production Economics, 131(2), 519-527.

Yam, R. C. M., Lo, W., Tang, E. P. Y., \& Lau, A. K. W. (2011). Analysis of sources of innovation, technological innovation capabilities, and performance: An empirical study of Hong Kong manufacturing industries. Research Policy, 40(3), 391-402.

Yen, D. A., \& Abosag, I. (2016). Localization in China: how guanxi moderates Sino-US business relationships. Journal of Business Research, 69(12), 5724-5734.

Yen, Y.-X. (2018). Buyer-supplier collaboration in green practices: The driving effects from stakeholders, Business Strategy and the Environment, 27(8): 1666-1678.

Yin, J., \& Zhang, Y. (2012). Institutional dynamics and corporate social responsibility (CSR) in an emerging country context: Evidence from China. Journal of Business Ethics, 111(2), 303-316.

Zeng, H., Chen, X., Xiao, X., \& Zhou, Z. (2017). Institutional pressures, sustainable supply chain management, and circular economy capability: Empirical evidence from Chinese ecoindustrial park firms. Journal of Cleaner Production, 155, 54-65.

Zeng, S. X., Xie, X. M., \& Tam, C. M. (2010). Relationship between cooperation networks and innovation performance of SMEs. Technovation, 30(3), 181-194.

Zhang, B., Bi, J., Yuan, Z. W., Ge, J. J., Liu, B. B., \& Bu, M. L. (2008). Why do firms engage in environmental management? An empirical study in China. Journal of Cleaner Production, 16, 1036-1045.

Zhang, C., Zeng, D. Z., Mako, W. P. \& Seward, J. (2009). Promoting Enterprise-Led Innovation in China. Hemdon VA: World Bank.

Zhang, F., \& Zhu, L. (2019). Enhancing corporate sustainable development: Stakeholder pressures, organizational learning, and green innovation. Business Strategy and the Environment, 28(6), 1012-1026.

Zhang, J., Liang, G., Feng, T., Yuan C., and Jiang, W. (2020). Green innovation to respond to environmental regulation: How external knowledge adoption and green absorptive capacity matter? Business Strategy and the Environment, 29(1), 39-53.

Zhang, L., Mol, A. P., \& He, G. (2016). Transparency and information disclosure in China's environmental governance. Current Opinion in Environmental Sustainability, 18, 17-24.

Zhu, Q., Cordeiro, J., \& Sarkis, J. (2012a). International and domestic pressures and responses of Chinese firms to greening, Ecological Economics, 83, 144-153.

Zhu, Q., Qu, Y., Geng, Y., \& Fujita, T. (2017). A comparison of regulatory awareness and green supply chain management practices among Chinese and Japanese manufacturers. Business Strategy and the Environment, 26(1), 18-30.

Zhu, Q., \& Sarkis, J. (2004). Relationships between operational practices and performance among early adopters of green supply chain management practices in Chinese manufacturing enterprises. Journal of Operations Management, 22(3), 265-289.

Zhu, Q., Sarkis, J., \& Lai, K. (2012b). Internationalization and environmentally-related organizational learning among Chinese manufacturers. Technological Forecasting \& Social Change, 79(1), 142-154.

Zubeltzu-Jaka, E., Erauskin-Tolosa, A., \& Heras-Saizarbitoria, I. (2018). Shedding light on the determinants of eco-innovation: A meta-analytic study. Business Strategy and the Environment, 27(7), 1093-1103. 


\section{TABLES}

\begin{tabular}{llc} 
Characteristics & Classification & $\begin{array}{c}\text { \% of } \\
\text { respondents }\end{array}$ \\
Respondent position & Top management & $4.1 \%$ \\
& Senior management & $51.4 \%$ \\
Industry & Aanagement & $44.6 \%$ \\
& Automotive manufacturing & $50.0 \%$ \\
& Electronics manufacturing & $24.6 \%$ \\
& Textile manufacturing & $25.5 \%$ \\
Percentage of ownership type & State owned & $10.9 \%$ \\
& Privately owned & $57.3 \%$ \\
& Foreign owned & $7.3 \%$ \\
& Other & $24.6 \%$ \\
Year of establishment & Before 1990s & $10.5 \%$ \\
& $1990 \mathrm{~s}$ & $35.5 \%$ \\
& $2000 \mathrm{~s}$ & $52.3 \%$ \\
Size of business & After 2010 & $1.8 \%$ \\
(number of employees) & 100 employees & $0.5 \%$ \\
& $100-500$ employees & $60.0 \%$ \\
Holding design patents in China & $500-2 \mathrm{k}$ employees & $32.7 \%$ \\
& $2 \mathrm{k}-10 \mathrm{k}$ employees & $6.8 \%$ \\
\hline Holding invention patents in China & Yes & $11.4 \%$ \\
& No & $88.6 \%$ \\
& No & $88.6 \%$ \\
& & $11.4 \%$
\end{tabular}

Table 1. Sample characteristics 


\begin{tabular}{|c|c|c|c|c|}
\hline $\begin{array}{l}\text { Construct/ } \\
\text { indicator }\end{array}$ & Loadings & $\begin{array}{l}\text { Cronbach's } \\
\text { Alpha }\end{array}$ & $\begin{array}{l}\text { Composite } \\
\text { Reliability (CR) }\end{array}$ & $\begin{array}{l}\text { Average } \\
\text { Variance } \\
\text { Extracted (AVE) }\end{array}$ \\
\hline Market Pressure & & 0.709 & 0.837 & 0.632 \\
\hline Market1 & $0.36 * * *$ & & & \\
\hline Market2 & $0.82 * * *$ & & & \\
\hline Market3 & $0.74 * * *$ & & & \\
\hline Community pressure & & 0.778 & 0.871 & 0.692 \\
\hline Communityl & $0.78 * * *$ & & & \\
\hline Community2 & $0.74 * * *$ & & & \\
\hline Community3 & $0.53 * * *$ & & & \\
\hline Regulatory pressure & & 0.698 & 0.867 & 0.765 \\
\hline Regulatory1 & $0.99 * * *$ & & & \\
\hline Regulatory2 & $0.55^{* * *}$ & & & \\
\hline Customer collaboration & & 0.704 & 0.839 & 0.641 \\
\hline Customerl & $0.27 * * *$ & & & \\
\hline Customer2 & $0.80 * * *$ & & & \\
\hline Customer3 & $0.90 * * *$ & & & \\
\hline Supplier collaboration & & 0.735 & 0.849 & 0.662 \\
\hline Supplier1 & $0.99 * * *$ & & & \\
\hline Supplier2 & $0.32 * * *$ & & & \\
\hline Supplier3 & $0.78 * * *$ & & & \\
\hline Product eco-innovation & & 0.790 & 0.825 & 0.616 \\
\hline Product1 & $0.92 * * *$ & & & \\
\hline Product2 & $0.93 * * *$ & & & \\
\hline Product3 & $0.46 * * *$ & & & \\
\hline Process eco-innovation & & 0.840 & 0.896 & 0.744 \\
\hline Process1 & $0.71 * * *$ & & & \\
\hline Process 2 & $0.99 * * *$ & & & \\
\hline Process3 & $0.62 * * *$ & & & \\
\hline
\end{tabular}

Note: ${ }^{*} \mathrm{p}<0.05 ; * * \mathrm{p}<0.01 ; * * * \mathrm{p}<0.001$

Table 2. Measurement model: loadings, composite reliability and convergent validity 


\section{$\begin{array}{lllllll}M P & \text { CP } & \text { RP } & \text { CC } & \text { SC } & \text { PDI } & \text { PCI }\end{array}$}

\section{Market Pressure}

(MP)

0.795

\section{Community}

Pressure (CP)

$0.018 \quad \mathbf{0 . 8 3 2}$

Regulatory

Pressure (RP)

$\begin{array}{lll}0.207 & -0.068 & \mathbf{0 . 8 7 5}\end{array}$

Customer

Collaboration (CC)

$\begin{array}{llll}0.232 & -0.084 & 0.119 & \mathbf{0 . 8 0 1}\end{array}$

Supplier

Collaboration (SC)

$\begin{array}{lllll}-0.041 & 0.237 & -0.066 & -0.021 & \mathbf{0 . 8 1 4}\end{array}$

Product Eco-

Innovation (PDI)

$$
\begin{array}{llllll}
-0.054 & 0.280 & -0.070 & -0.044 & 0.183 & \mathbf{0 . 8 6 3}
\end{array}
$$

Process Eco-

$\begin{array}{llllllll}\text { Process Eco- } & 0.084 & -0.019 & 0.100 & 0.216 & 0.015 & 0.090 & \mathbf{0 . 8 7 5}\end{array}$

Note: Bold numbers on the diagonal show the square root of the AVE; numbers below the diagonal represent construct correlations

Table 3. Measurement model: Intercorrelations and discriminant validity

\begin{tabular}{llllll}
\hline Model & $\chi^{\mathbf{2}}(\mathbf{d f})$ & Normed $\chi^{2}$ & CFI & RMSEA & IFI \\
\hline CFA & $197.71(152)$ & 1.301 & 0.967 & 0.037 & 0.968 \\
Path & $228.91(163)$ & 1.404 & 0.953 & 0.043 & 0.954 \\
\hline
\end{tabular}

Note: $\mathrm{CFI}=$ Confirmatory Fit Index; RMSEA = Root Mean Square Error of Approximation; $\mathrm{IFI}=$ Bollen's Incremental Fit Index

Table 4. Fit indices of covariance-based model (CFA) and path model 


\section{FIGURES}

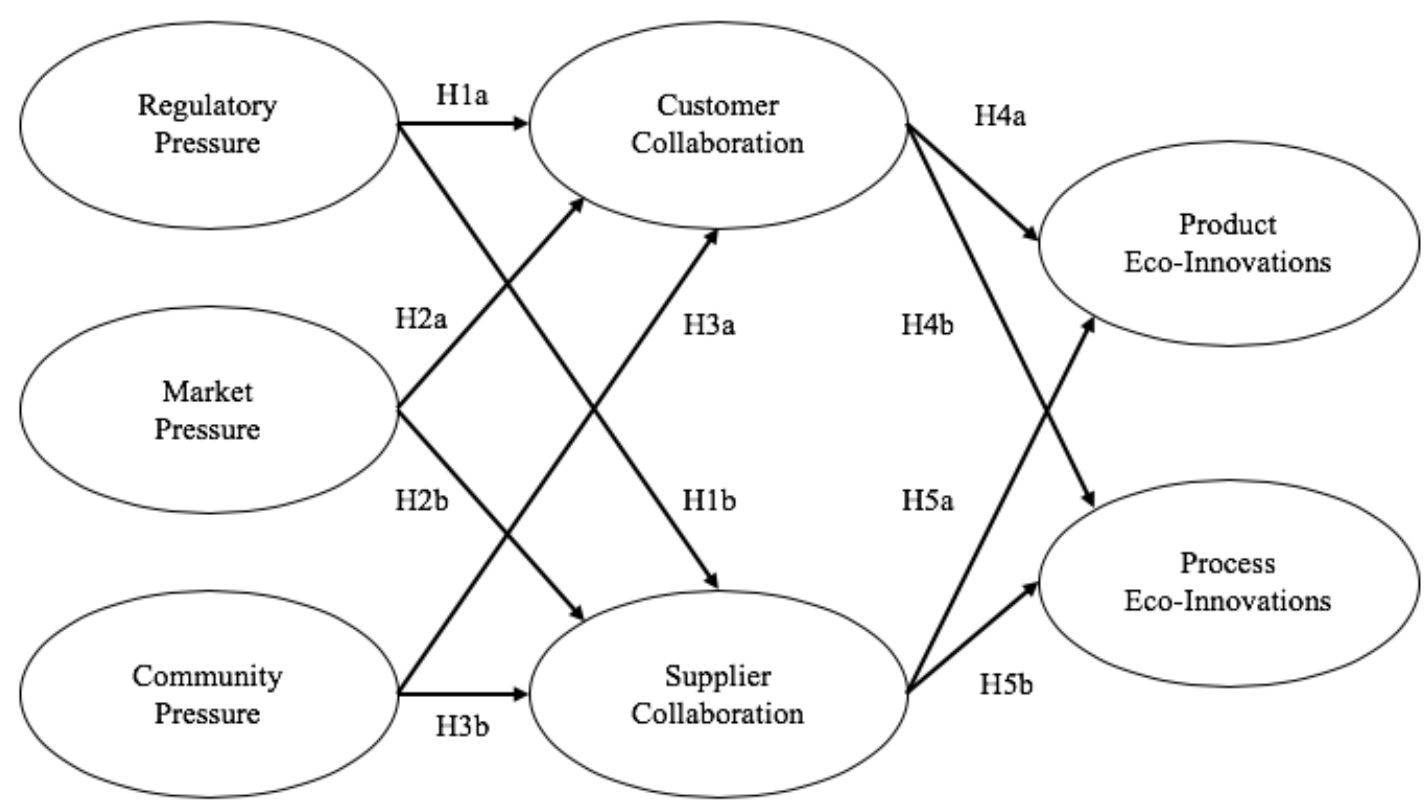

Figure 1. Conceptual model and hypotheses

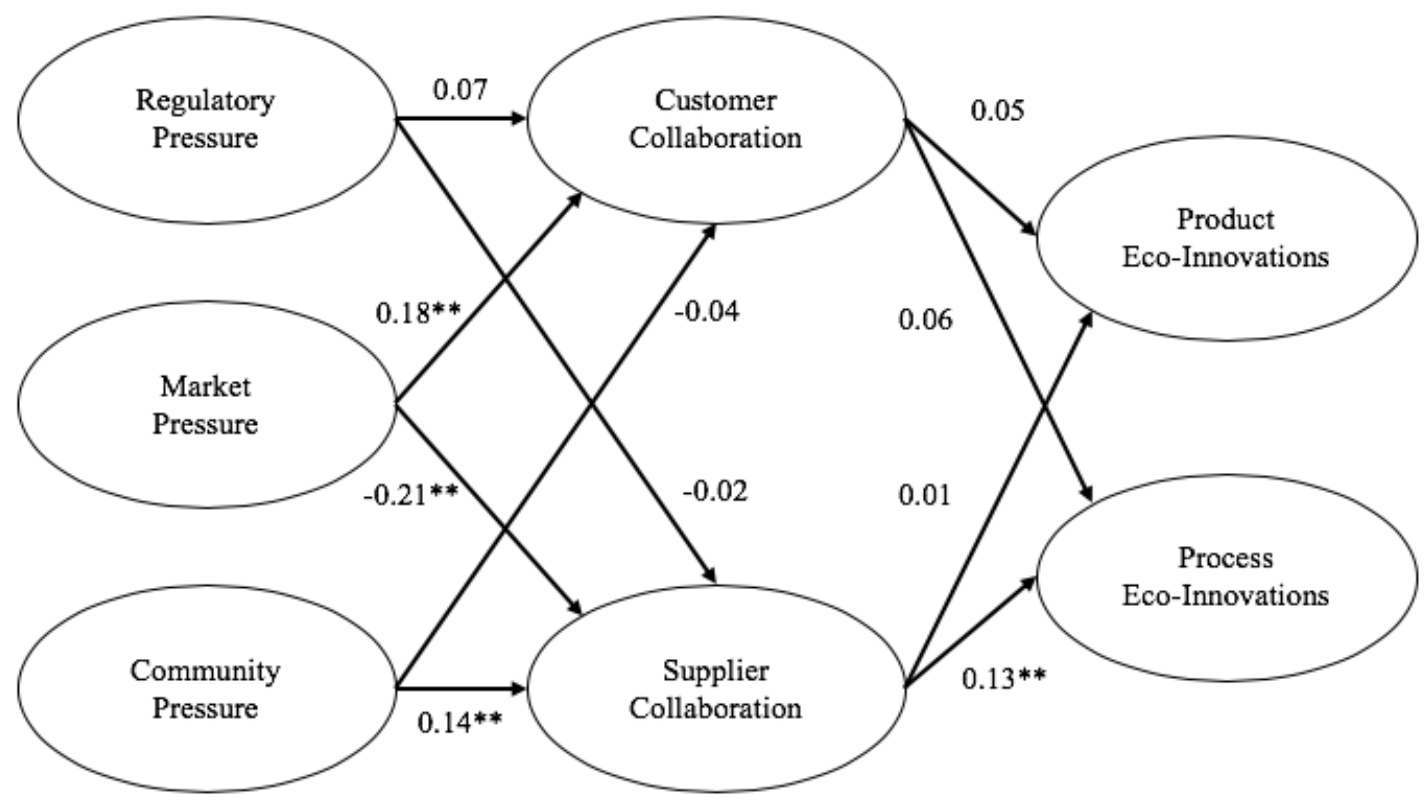

Figure 2. Resulting path model 


\section{APPENDIX:}

\section{Item Description}

Our firm develops eco-innovations as a response to: Having seen examples

Market1 of other firms that have reduced the environmental impacts of their products and processes.

Market2 Our firm develops eco-innovations as a response to: Future expected market demand from our customers for products with lower environmental impacts.

Market3 Our firm develops eco-innovations as a response to: Current market demand from our customers for products with lower environmental impacts.

Community1 Our firm develops eco-innovations as a response to: Government expectations for sustainable development and a harmonious society.

Community2 Our firm develops eco-innovations as a response to: Pressures from local neighborhoods \& residents to improve our environmental performance.

Our firm develops eco-innovations as a response to: Pressures from

Community3 environmental groups such as Friends of Nature, Greenpeace, Greenovation Hub, Environment Defense Fund to improve our environmental performance.

Regulatory1 Our firm develops eco-innovations as a response to: Future environmental regulations, laws or taxes that we expect to be introduced.

Regulatory2 Our firm develops eco-innovations as a response to: Existing environmental regulations, laws or taxes on pollution.

Customer1 Our customers provide crucial input for our eco-innovations.

Customer2 We collaborate with our customers to develop eco-innovations.

Customer3 We have learned from collaboration with our customers in the process to develop eco-innovations.

Supplier1 We collaborate with our suppliers to develop eco-innovations.

Supplier2 Our suppliers provide crucial input for our eco-innovations.

Supplier3

We obtain crucial input for our eco-innovations from our collaboration with universities and/or research institutes. 
Product1 Our firm has introduced new or improved products or services that are more environmentally-friendly than those already on the market.

Our firm has made small changes in our products that mainly involve small

Product2 adjustment in existing technologies and/or products with small reduction of environmental impacts.

Product3 Our firm has made changes in our products that have realized substantial reductions in environmental impacts of our products.

Process1 Our firm has made eco-innovations that led to (near to) complete removal of hazardous substances in our production process.

Process 2 Our firm has made big changes in our production processes that led to (close to) zero emission of waste.

Process 3

Our firm has made big changes in our production processes that led to (close to) zero emission of wastewater.

Appendix A. Survey questionnaire 